\title{
Rock masses stresses investigation based on overcoring with CSIRO cell test and 3D finite element modeling in Aqabat Al-Sulbat Road at Aseer Province, Saudi Arabia: Numerical approach
}

\author{
Hamdi Ayed*,**, Khaled Mohamed Khedher*,*** and Abir Mouldi****,** \\ *Department of Civil Engineering, College of Engineering, King Khalid University, Abha - 61421, KSA \\ **Higher Institute of Transport and Logistics of Sousse, University Sousse, Tunisia \\ ***Department of Civil Engineering, ISET, Nabeul, DGISET, Tunisia \\ ****Department of Industrial Engineering, College of Engineering, King Khalid University, Abha - 61421, KSA \\ Corresponding author: hayed@kku.edu.sa
}

Submitted: 05/02/2019

Revised: $\quad 24 / 11 / 2020$

Accepted: $14 / 12 / 2020$

\begin{abstract}
Rock masses slopes stability is a real problem and represents an important concern in Aseer Province, in order to avoid rock fall process on the main roads. For this reason, it is necessary to explore, inspect, investigate, and understand the natural stresses within these rock masses taking into a consideration the third dimension. In this sense, the state of stresses within the rock masses depends on the characteristics of Commonwealth Scientific and Industrial Research Organization (CSIRO) cell and the dimension of the overcoring hole. Furthermore, in order to achieve the 3D modeling, the characteristics of the rock masses mentioned before are introduced in the model using "Surfrac" program written in Pascal and FORTRAN, coupled with "Abaqus" software to simulate the stresses matrix in the model. As a result, the main findings of this research are summarized in three points: the first is dealing with the CSIRO cell itself, where the direction of the gauge is important during the measurement of stresses; in fact, the perpendicular gauges work better than those parallel to the hole axis. The second is evident from the model that the direction of hole must be perpendicular to the dip direction of the rock layers, allowing giving better results compared to others. The third is the selection of the measurement site requiring involving the regional stresses of the study area according to geological investigation. Finally, it is interesting to carry out geophysical exploration in the site to understand the local tectonic movement of rock masses. Moreover, a detailed map can highlight the main fractures and faults network and overlap them with the most important projects deployed in Aseer province for maintenance and monitoring.
\end{abstract}

Keywords: Aseer province; Rock masses; Overcoring CSIRO cell test; Natural stresses; 3D modeling; Isotropic and anisotropic medium.

\section{INTRODUCTION}

In general, the stresses measurement in the rock masses especially in the mountainous Aseer province in Saudi Arabia is one of the most important demands for the design, implementation, and maintenance of major projects in Civil and Mining Engineering (Highways, Tunnels, Bridges, Open pit quarries for building materials, and all sector 
of mining). In fact, to find out the natural stresses matrix within the rocks masses, there is a need to resort to 3D modeling using finite element method and more (Ouanas, 2010), and comparing them with the field experiments by measuring strain using CSIRO cell become urgent (Amadei, 1995). Because of the high cost of the field experiments, the results of the measurement CSIRO cell as a basic method in the knowledge of three-dimensional stresses matrix and other methods are considered to be extremely useful in the face of the rise of computer applications and modeling in this field (Lahaie, 2010). However, the most important difficulties encountered by researchers and those interested in measuring the stresses within the rocks masses are the complexity of tectonic plates and the characteristics of the natural, artificial rock joints, and faults network observed and hidden within the rock masses (Gomez et al., 2007; ElHussain et al., 2018; Dief et al., 2017; Bosworth et al., 2005). In addition, we involve the dynamic changes witnessed by terrestrial plates under the sea and in the continents due to the continuous seismic movement of the crust of the earth (El-Hussain et al., 2017; Gomez et al., 2007). However, the technique of measuring relaxation rock masses based on the overcoring method and CSIRO cell started by executing first borehole in the rock masses, digging a second hole inside the first, then entering the CSIRO cell, and finally cutting it and making all processing to visualize the results (Lahaie, 2010; Ouanas, 2010). In this context, the CSIRO cell is designed with twelve gauges having wellknown orientations on the cell, through which we know the three-dimensional relaxation and the characteristics of the CSIRO cell and the rock masses. In this sense, the natural stresses matrix can be estimated within the concerned rock masses (Amadei et al., 1995; Godman, 1985). In the same way, and regarding the history of the overcoring method, the first experiment was proposed by an instrument placed in shallow depth (10 to $20 \mathrm{~m})$ in a small borehole with diameter of $25 \mathrm{~mm}$ (Hast, 1958). Moreover, in the next decades, the overcoring method has been more developed by carrying out twenty-two strain measurements especially using the CSIRO cell (Worotnicki \& Walton, 1976). Furthermore, with the beginning of the eighties, the CSIRO cell began to spread in international universities and became interesting in the mining industry especially in western countries such as United States of America, Australia, and Europe (Amadei, 1983; Amadei, 1984; Amadei et al., 1985; Amadei \& Savage, 1985; Amadei et al., 1987; Amadei et al., 1988). In the same period, the annual international scientific symposium specialized in rock mechanics became more and more interesting and attracted many researchers from around the world: Australian and Chinese universities, as well as South Africa companies active in mining engineering and working in natural resources (such as iron, gold, coal, and phosphates). They are interested in applying CSIRO cell to measure natural stresses in the field. In the same way, in order to understand the deep underground openings behavior, many researches around the world have developed this technique (Baroudi \& Revalor, 1994, Brady et al., 1989; Chambon \& Revalor, 1986; Cai et al., 1995). In the same time, the CSIRO cell has appeared in Australia, and its name corresponds to a big organization active in multidisciplinary activities (Commonwealth Scientific and Industrial Research Organization), which is an independent Australian federal government agency responsible for scientific research. In fact, its chief role is to improve the economic and social performance of industry for the benefit of the community around the world not only in Australia. In this moment, the company manufactures the CSIRO cell named ESS Earth Science, and it is located in Australia (CSIRO, 2019). Nowadays, and with the beginning of the twenty-first century, the world witnessed an unprecedented revolution concerning the computer science development, and of course, the applications of the computer science in all other specialties, in particular, the mining engineering. For this reason, in parallel with filed measurement using CSIRO cell, many applied research works have been carried out, dealing with modeling especially using finite element method to compare the results conducted in the field (Cai, 1990; Khedher, 1992; Fouail, 1997; Chikhaoui, 2009; Ouanas, 2010). In addition, many research works have been conducted in many universities around the world interested in developing the CSIRO cell measurement and carrying out modeling and simulations using different programs (Cai et al., 1995; Amadei, 1996; Hakala et al., 2003; Hakala, 2006; Lahaie, 2006; Lahaie, 2010). 


\section{STUDY AREA AND PROBLEM}

\section{Study area}

Safety roads are typically indispensable in several regions across all urban areas and mountainous zones in Aseer Province (Figure 1: a and b). Located either in the vicinity of planning urban zones or rock mountains region, most road networks are located at the boundary between Aseer and Al Baha Provinces in a location named Al-Sulbat situated $5 \mathrm{~km}$ north-west of Khatheam Village within dangerous rock slopes reaching more than $2000 \mathrm{~m}$ of altitude. This section road between Aseer and Al Baha allows serving land transportation serving transport people and goods between the southern provinces in the Kingdom of Saudi Arabia (KSA). With a maximum height of $2260.4 \mathrm{~m}$, influencing study site can involve over $900 \mathrm{~km}^{2}$ including all the natural triggered factors (geology, morphology, roads network, lineaments and hydrology, urban areas, etc.). With respect to urban areas, nearby the study site, the mountains represent important conditions for roads network safety (Aseer Municipality, 2020a, 2020b, 2020c). The study site (Latitude $19^{\circ} 42^{\prime}-19^{\circ} 52^{\prime}$ North, Longitude $41^{\circ} 40^{\prime}-41^{\circ} 50^{\prime}$ East) lies north-west of Aseer Province that is located between Beljarshi mountainous series in the north-west and Khatheam Village in the south-east. In addition, the site and its neighborhoods cover about $90 \times 10^{3}$ hectares, taking part of an important tourist province in KSA. Urban planning represents more than $30 \%$ of the site; agricultural lands represent $20 \%$, while rock mountains areas represent $50 \%$. As reported in a geotechnical report (Aseer Municipality, 2020a), and according to vision 2030, the transportation demand in KSA can reach $30 \%$ of land transportation such as vehicles (cars, Lorries, and heavy tracks). Moreover, Aseer Province is considered as semiarid area in the south of KSA where the temperature in the summer reaches $35^{\circ} \mathrm{C}$ and decreasing until $7^{\circ} \mathrm{C}$ in the winter. The annual rainfall varies between $350 \mathrm{~mm}$ yearly in the south-west and $150 \mathrm{~mm}$ yearly in the northeast. Finally, more details about environmental and climatological conditions can be found in the final reports of Aseer Municipality (Aseer Municipality, 2020a, 2020b, 2020c). Aqabat Al-Sulbat lies in the heart Arabian shield in the west south of KSA, which is an exposure of Precambrian age crystalline rocks on the Eastern bank of the Red Sea. In fact, referring to the final reports collected from Aseer Municipality (Aseer Municipality, 2019a, 2019b, 2019c), the essential findings concerning the field geotechnical investigations are summarized below (Figure 2: a and b). In fact, 16 boreholes have been straightly carried out in the road section, where the depth reaches a maximum of $35 \mathrm{~m}$. Furthermore, from each borehole, rock samples have been taken by overcoring drilling method. Moreover, all the samples collected from all boreholes confirmed that the rock units depending on depth are metamorphic and plutonic (andesite, basalt, and dacite). Otherwise, because of identifying the rock quality along with the drilling depth, a geotechnical procedure has been performed to judge the rock quality designation (RQD), the fractured Index (FI), and supplementary laboratory testing performed to measure the unconfined compression strength (UCS) of each sample. However, to realize this methodology, an important field investigation testing was carried out to collect the essential structural features and characterize the more important natural triggered factors. Moreover, geotechnical field measurements have been achieved by Aseer Municipality within the framework of geotechnical investigations for achieving the design and implementation of the Civil Engineering works along the road section. Among these, geotechnical data concerning the rock quality and structural features (geological and mechanical discontinuities) were collected (Aseer Municipality, 2019a, 2019b, 2019c). In fact, we distinguish the RQD, the influence of weathering on rock layers, the structural features (dip, dip direction, spacing, and faults filling), and also the slopes geometry (dip, dip direction, and height of slopes). And many photos and visual observations have been performed to estimate the state of rock layered slopes straightly in the Al-Sulbat road section (Figure 3: a, b, and c). 


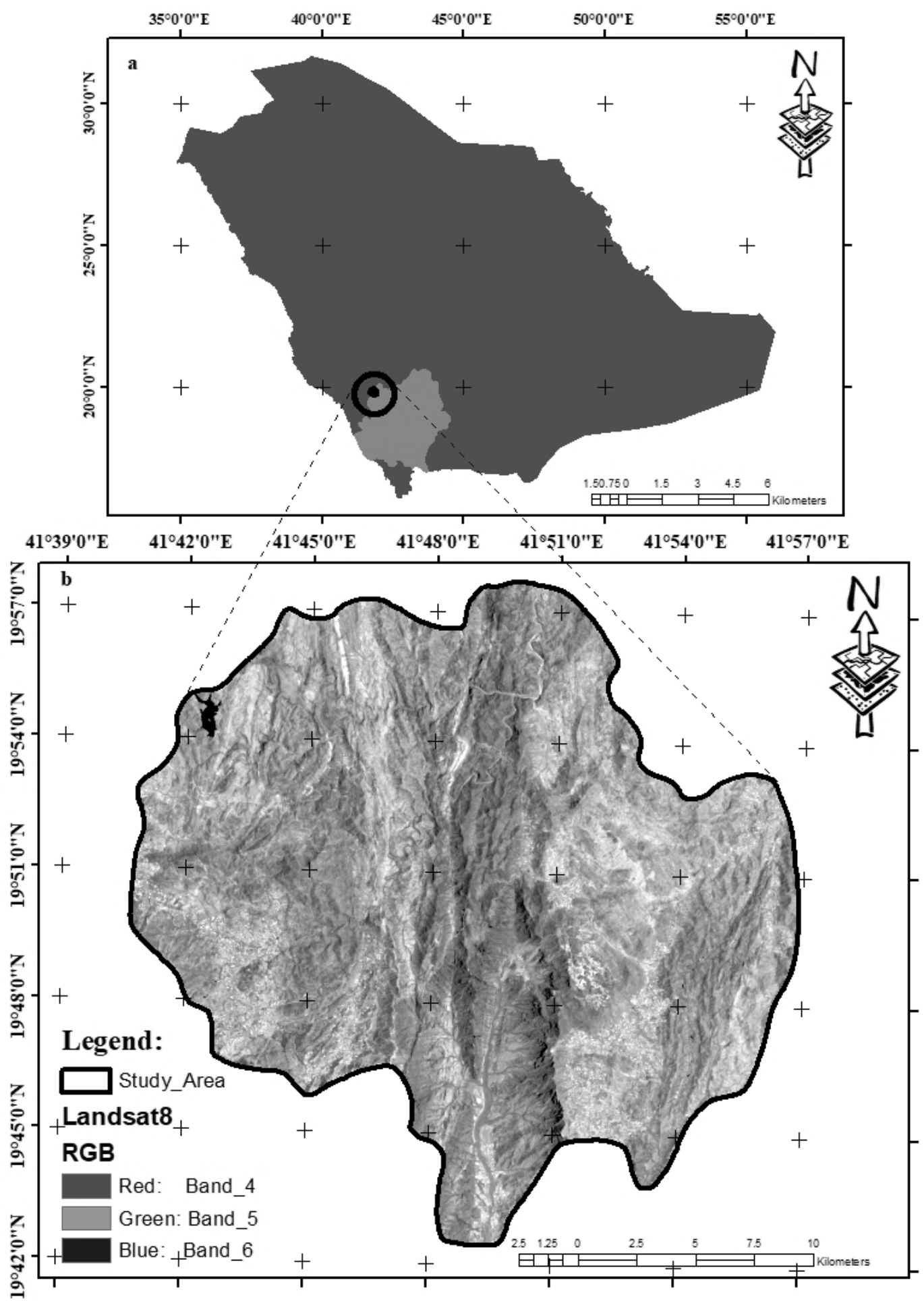

Figure 1. Study Area in the South of Saudi Arabia.

(a: Saudi Arabia boundaries; b: Aseer province boundaries). 


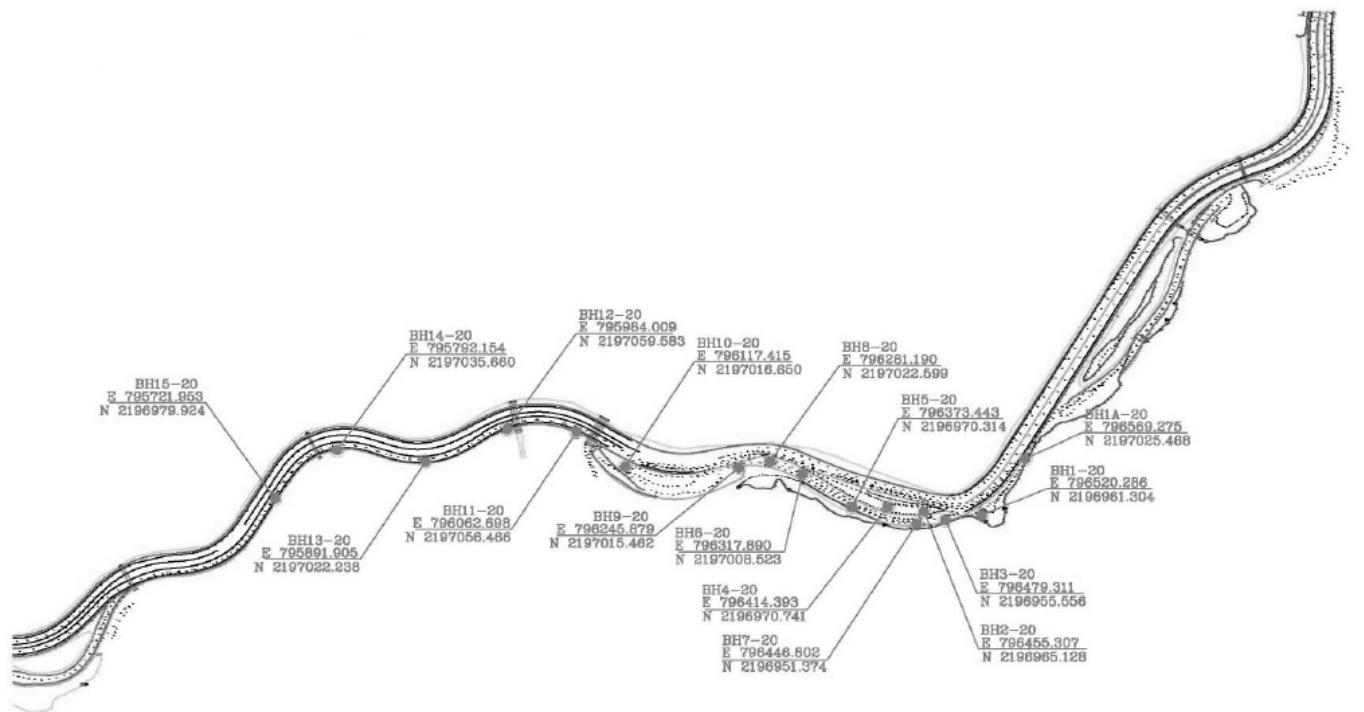

(a)

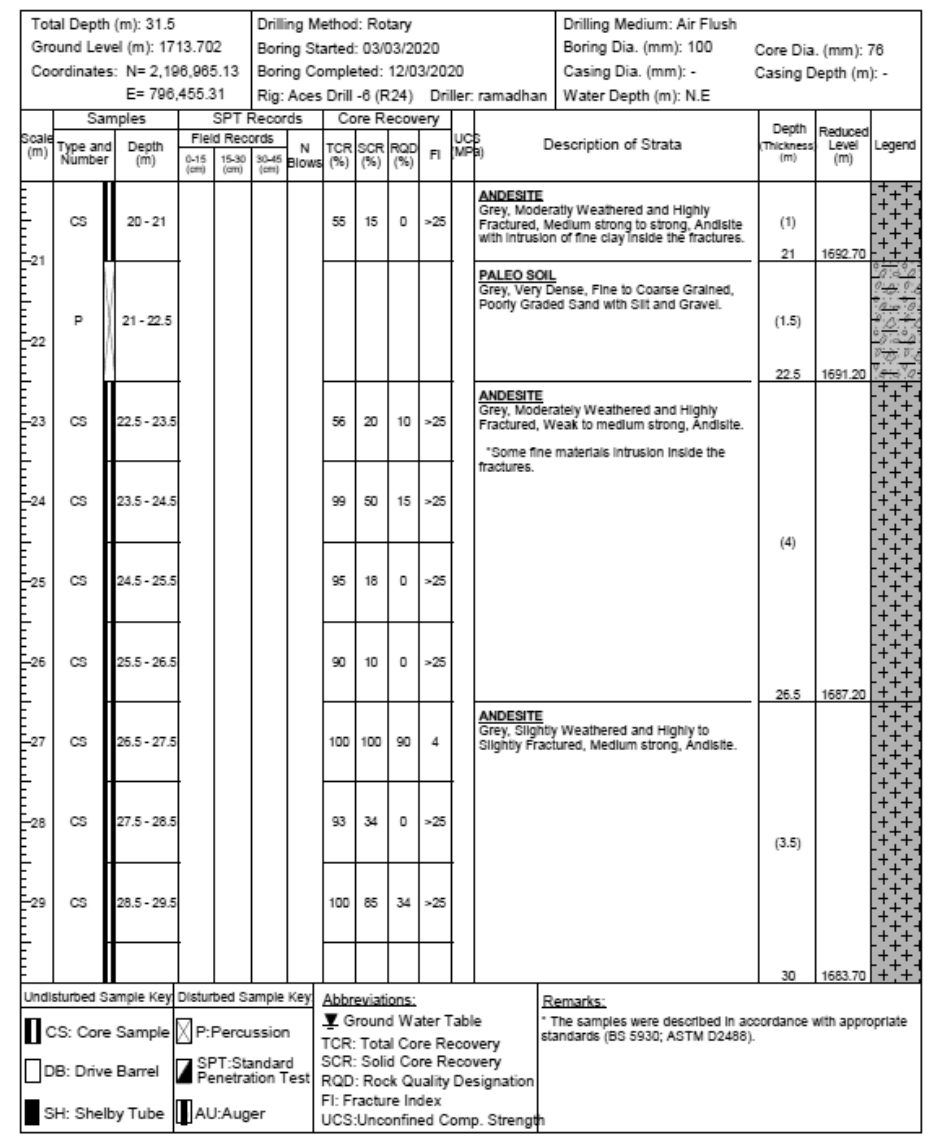

(b)

Figure 2. Borehole layout and geotechnical findings (Aseer Municipality, 2019a).

(a) Number of boreholes carried out. (b) Lithology and main geotechnical characteristics. 


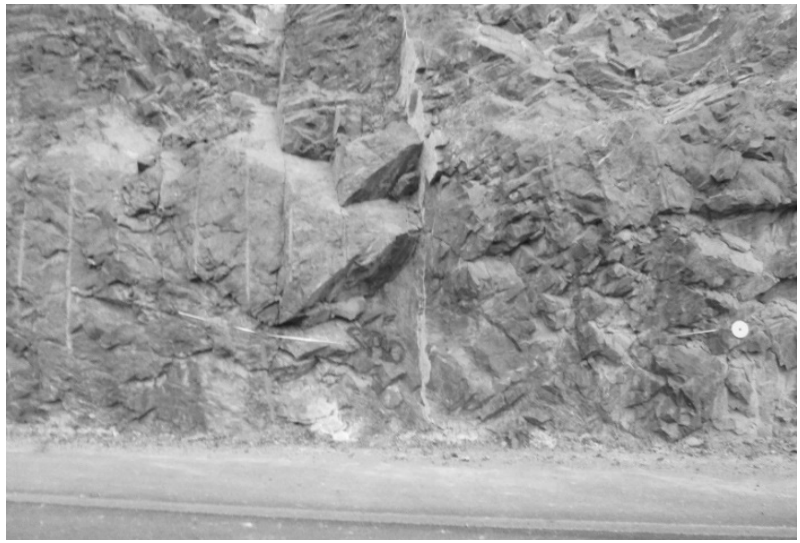

(a)

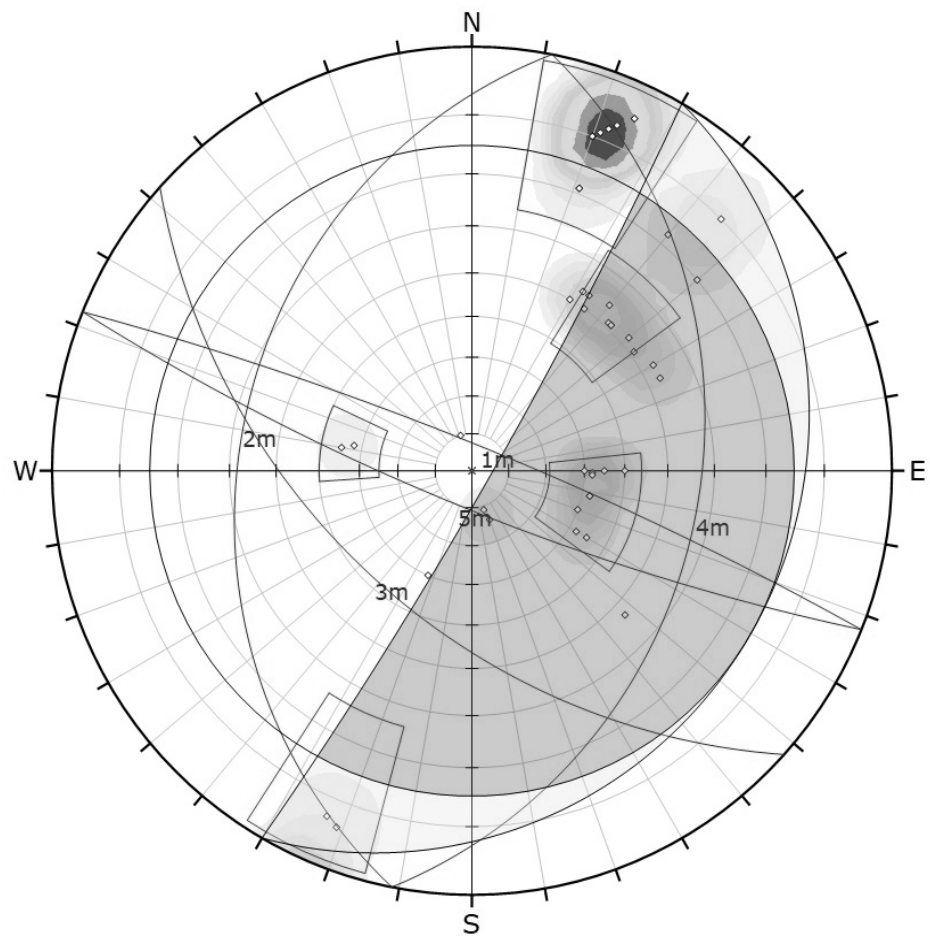

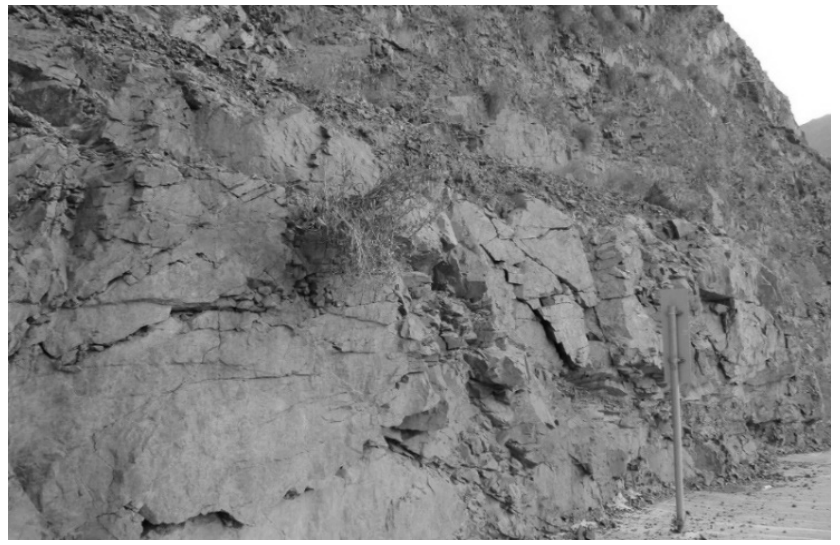

(b)

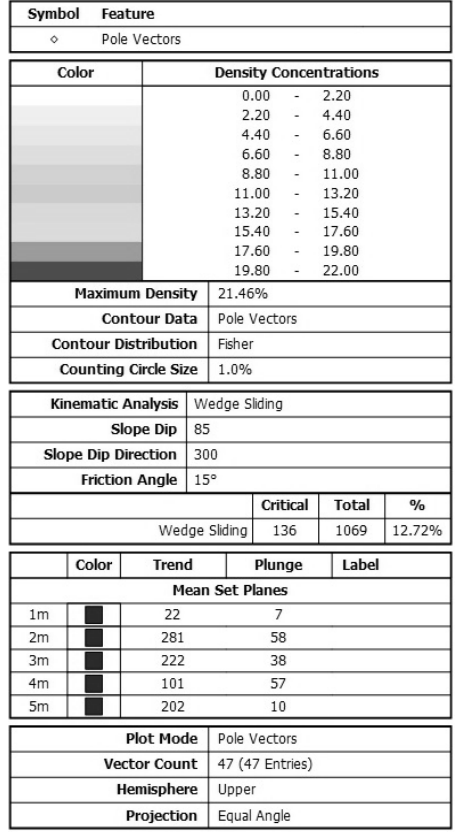

(c)

Figure 3. Kinematic analysis of discontinuities sets using Dips Software.

(a) Discontinuities network measured at Station 10. (b) Slope with key blocks. (c) Stereographic projection.

\section{Problem}

Because Aseer province is of utmost importance to domestic tourism, as this province is rich in scenic landscapes and mountainous highlands. In view of the risks of rock fall nearby the main roads and the old tunnels and the new residential plans that are consistent day after day in the unpaved mountain sites, for these reasons, and with the continuous encouragement of King Khalid University, which represents the research pole in this province, to support all applied research related to the urban planning and expand and maintain the road network within the province and investigate land cover and land use in order to protect the infrastructures against the rock fall in the future, in this 
context, in the first stage, in the study area, geological and geotechnical exploration and investigation were achieved using new technologies such as Remote Sensing and Geographical Information Systems (GIS). In addition, 3D modeling, as well as field experiments, was conducted in order to estimate the natural stresses components within the rock masses in different locations (Aseer Municipality, 2020a). Moreover, other provinces in Saudi Arabia should be investigated in the second stage in the future. Otherwise, due to the high cost of field experiments of stresses, as well as measurement in the rock masses (Ouanas, 2010), the research team considered the importance to start by exploring the whole province through field visits and through Remote Sensing and satellite images (Aseer Municipality, 2020a). In this context, this stresses measurement allows to draw digital mapping that identifies the problem overlapping with the most important fixed facilities and natural components in this study area (Aseer Municipality, 2020a). In addition, the research team is conducting numerical modeling using three-dimensional models based on 3D finite element Software and program that simulated the strain within CSIRO cell using the overcoring method in the field experiment (Fouial et al., 1995). Furthermore, Aseer province is located on the edge of the horizontal tectonic movement of the African continent towards the Asian continent and represents a Saudi Arabia land (El-Hussain, 2017). In fact, the tectonic movement of speeding up to $10 \mathrm{~mm}$ per year and the connection of the Saudi Arabia land with Asian continent, and especially the Iranian land, made this movement decrease in the rest of the Eastern part of the Kingdom. Moreover, we identify, in the Eastern part of Iran, recorded important seismic activities (Dief et al., 2007). Therefore, due to the lack of research in this field (rock mechanics and geotechnical engineering) in the Southern provinces, it is important to work on a map to visualize the trends and magnitudes of the natural stresses in several sites. In addition, in the same province, many natural factors such as plates tectonic movement, seismic activities, network of geological faults, and of course the network mechanical fractures accompanying the main faults can be overlapped within the geo-database.

\section{THEORETICAL ASPECTS \\ Case of isotropic rock medium}

For isotropic medium, especially rocks, we can apply law of Hooke, which is given by

$\varepsilon_{i j=[A] . \sigma_{i j}}$

where

$\varepsilon_{\mathrm{ij}}$ : the strain element of the vector;

[A]: the matrix representing the characteristics of the rock masses;

$\sigma_{\mathrm{ij}}$ : the stress component of the stresses vector.

According to rock mechanics behavior, the matrix representing the characteristics of the rock masses is often symmetric and written as follows (Godman, 1980):

$$
[A]=\left[\begin{array}{cccccc}
\frac{1}{E} & -\frac{v}{E} & -\frac{v}{E} & 0 & 0 & 0 \\
-\frac{v}{E} & \frac{1}{E} & -\frac{v}{E} & 0 & 0 & 0 \\
-\frac{v}{E} & -\frac{v}{E} & \frac{1}{E} & 0 & 0 & 0 \\
0 & 0 & 0 & \frac{2(1+v)}{E} & 0 & 0 \\
0 & 0 & 0 & 0 & \frac{2(1+v)}{E} & 0 \\
0 & 0 & 0 & 0 & 0 & \frac{2(1+v)}{E}
\end{array}\right]
$$

In the same way, the above constitutive equation of Hooke's law is given as follows: 
$\left[\begin{array}{c}\varepsilon_{x} \\ \varepsilon_{x} \\ \varepsilon_{x} \\ \gamma_{x y} \\ \gamma_{x z} \\ \gamma_{y z}\end{array}\right]=\left[\begin{array}{cccccc}\frac{1}{E} & -\frac{v}{E} & -\frac{v}{E} & 0 & 0 & 0 \\ -\frac{v}{E} & \frac{1}{E} & -\frac{v}{E} & 0 & 0 & 0 \\ -\frac{v}{E} & -\frac{v}{E} & \frac{1}{E} & 0 & 0 & 0 \\ 0 & 0 & 0 & \frac{2(1+v)}{E} & 0 & 0 \\ 0 & 0 & 0 & 0 & \frac{2(1+v)}{E} & 0 \\ 0 & 0 & 0 & 0 & 0 & \frac{2(1+v)}{E}\end{array}\right] \cdot\left[\begin{array}{c}\sigma_{x} \\ \sigma_{y} \\ \sigma_{z} \\ \tau_{y z} \\ \tau_{x z} \\ \tau_{x y}\end{array}\right]$

where

E: Young's modulus in $\mathrm{x}, \mathrm{y}$, and $\mathrm{z}$ directions, respectively;

$v$ : Poisson's ratios in each plane of isotropic medium according to $\mathrm{x}, \mathrm{y}$, and $\mathrm{z}$, respectively;

$\gamma$ : the shear strain in each plane of isotropic medium according to $\mathrm{x}, \mathrm{y}$, and $\mathrm{z}$, respectively;

$\tau$ : the shear stress component in each plane of isotropic medium according to $\mathrm{x}, \mathrm{y}$, and $\mathrm{z}$, respectively.

\section{Case of anisotropic rock medium}

For anisotropic medium, especially rocks also, we can apply law of Hooke, which is expressed by the following and the same form given above in (1).

According to rock mechanics behavior, the matrix representing the characteristics of the rock masses is often symmetric and can be written as the following form taking into account the stratification of rock layers in $\mathrm{x}, \mathrm{y}$, and $\mathrm{z}$ directions (Wang et al., 2018):

$$
[A]=\left[\begin{array}{cccccc}
\frac{1}{E_{x}} & -\frac{v_{x y}}{E_{y}} & -\frac{v_{x z}}{E_{z}} & 0 & 0 & 0 \\
-\frac{v_{x y}}{E_{x}} & \frac{1}{E_{y}} & -\frac{v_{y z}}{E_{y}} & 0 & 0 & 0 \\
-\frac{v_{x y}}{E_{x}} & -\frac{v_{y z}}{E_{y}} & \frac{1}{E_{y}} & 0 & 0 & 0 \\
0 & 0 & 0 & \frac{1}{G_{y z}} & 0 & 0 \\
0 & 0 & 0 & 0 & \frac{1}{G_{x y}} & 0 \\
0 & 0 & 0 & 0 & 0 & \frac{1}{G_{x z}}
\end{array}\right]
$$

In the same way, the above constitutive equation of Hooke's law is given as follows:

$$
\left[\begin{array}{c}
\varepsilon_{x} \\
\varepsilon_{x} \\
\varepsilon_{x} \\
\gamma_{x y} \\
\gamma_{x z} \\
\gamma_{y z}
\end{array}\right]=\left[\begin{array}{cccccc}
\frac{1}{E_{x}} & -\frac{v_{x y}}{E_{y}} & -\frac{v_{x z}}{E_{z}} & 0 & 0 & 0 \\
-\frac{v_{x y}}{E_{x}} & \frac{1}{E_{y}} & -\frac{v_{y z}}{E_{y}} & 0 & 0 & 0 \\
-\frac{v_{x y}}{E_{x}} & -\frac{v_{y z}}{E_{y}} & \frac{1}{E_{y}} & 0 & 0 & 0 \\
0 & 0 & 0 & \frac{1}{G_{y z}} & 0 & 0 \\
0 & 0 & 0 & 0 & \frac{1}{G_{x y}} & 0 \\
0 & 0 & 0 & 0 & 0 & \frac{1}{G_{x z}}
\end{array}\right] \cdot\left[\begin{array}{c}
\sigma_{x} \\
\sigma_{y} \\
\sigma_{z} \\
\tau_{y z} \\
\tau_{x z} \\
\tau_{x y}
\end{array}\right]
$$


where

E: Young's modulus in $\mathrm{x}, \mathrm{y}$, and $\mathrm{z}$ directions, respectively;

$v$ : Poisson's ratios in each plane of isotropic medium according to $\mathrm{x}, \mathrm{y}$, and $\mathrm{z}$, respectively;

$\gamma$ : the shear strain in each plane of isotropic medium according to $\mathrm{x}, \mathrm{y}$, and $\mathrm{z}$, respectively;

$\tau$ : the shear stress component in each plane of isotropic medium according to $\mathrm{x}, \mathrm{y}$, and $\mathrm{z}$, respectively.

Passing matrix from Polar to Cartesian coordinates (Brady \& Brown, 2004; Ouanas, 2010),

$$
\left[\begin{array}{l}
\varepsilon_{r r} \\
\varepsilon_{\theta \theta} \\
\varepsilon_{z z} \\
\gamma_{\theta z} \\
\gamma_{r z} \\
\gamma_{r \theta}
\end{array}\right]=\left[\begin{array}{cccccc}
\cos ^{2} \theta & \sin ^{2} \theta & 0 & 0 & 0 & \sin (2 \theta) \\
\sin ^{2} \theta & \cos ^{2} \theta & 0 & 0 & 0 & -\sin (2 \theta) \\
0 & 0 & 1 & 0 & 0 & 0 \\
0 & 0 & 0 & \cos \theta & -\sin \theta & 0 \\
0 & 0 & 0 & \sin \theta & \cos \theta & 0 \\
\frac{-\sin (2 \theta)}{2} & \frac{\sin (2 \theta)}{2} & 0 & 0 & 0 & \cos (2 \theta)
\end{array}\right] \cdot\left[\begin{array}{c}
\varepsilon_{x} \\
\varepsilon_{x} \\
\varepsilon_{x} \\
\gamma_{x y} \\
\gamma_{x z} \\
\gamma_{y z}
\end{array}\right]
$$

Passing principal stresses matrix to the natural stresses in $\mathrm{x}, \mathrm{y}$, and $\mathrm{z}$ coordinates (Amadei, 1997),

$$
\left[\begin{array}{ccc}
\sigma_{x x} & \tau_{x y} & \tau_{x z} \\
\tau_{y x} & \sigma_{y y} & \tau_{y z} \\
\tau_{z x} & \tau_{z y} & \sigma_{z z}
\end{array}\right]=\left[\begin{array}{ccc}
l_{1} & l_{2} & l_{3} \\
m_{1} & m_{2} & m_{3} \\
n_{1} & n_{2} & n_{3}
\end{array}\right] \cdot\left[\begin{array}{ccc}
\sigma_{1} & 0 & 0 \\
0 & \sigma_{2} & 0 \\
0 & 0 & \sigma_{3}
\end{array}\right] \cdot\left[\begin{array}{ccc}
l_{1} & m_{1} & n_{1} \\
l_{2} & m_{2} & n_{2} \\
l_{3} & m_{3} & n_{3}
\end{array}\right]
$$

This gives the following equations:

$$
\begin{aligned}
& \sigma_{x x}=l_{1}^{2} \sigma_{1}+l_{2}^{2} \sigma_{2}+l_{3}^{2} \sigma_{3} ; \sigma_{y y}=m_{1}^{2} \sigma_{1}+m_{2}^{2} \sigma_{2}+m_{3}^{2} \sigma_{3} \\
& \sigma_{z z}=n_{1}^{2} \sigma_{1}+n_{2}^{2} \sigma_{2}+n_{3}^{2} \sigma_{3} ; \tau_{x y}=l_{1} m_{1} \sigma_{1}+l_{2} m_{2} \sigma_{2}+l_{3} m_{3} \sigma_{3} \\
& \tau_{x y}=m_{1} n_{1} \sigma_{1}+m_{2} n_{2} \sigma_{2}+m_{3} n_{3} \sigma_{3} ; \tau_{x y}=l_{1} n_{1} \sigma_{1}+l_{2} n_{2} \sigma_{2}+l_{3} n_{3} \sigma_{3} \\
& {\left[\begin{array}{ccc}
l_{1} & l_{2} & l_{3} \\
m_{1} & m_{2} & m_{3} \\
n_{1} & n_{2} & n_{3}
\end{array}\right]=\left[\begin{array}{ccc}
\cos \psi \cos \varphi-\sin \psi \cos \theta \sin \varphi & -\cos \psi \cos \varphi-\sin \psi \cos \theta \cos \varphi & \sin \psi \sin \theta \\
\sin \psi \cos \varphi+\cos \psi \cos \theta \sin \varphi & -\sin \psi \sin \varphi+\cos \psi \cos \theta \sin \varphi & -\cos \psi \cos \theta \\
\sin \theta \sin \varphi & \sin \theta \cos \varphi & \cos \theta
\end{array}\right]}
\end{aligned}
$$

where

$\theta, \varphi$, and $\psi$ are Euler angles (Khedher, 1992).

\section{Principle of least squares method used in "Surfrac" program}

The least squares method has been developed in the "Surfrac" program, while introducing a calculation error in the form of a model, in order to optimize the dip and the dip direction of the bore hole, and also to identify the behavior of each gauge within the CSIRO cell (Khedher, 1992).

Referring to the natural stresses matrix, we can write the following equation:

$Y_{i}=a_{1 i} \sigma_{x}+a_{2 i} \sigma_{y}+a_{3 i} \sigma_{z}+a_{4 i} \tau_{x y}+a_{5 i} \tau_{x z}+a_{6 i} \tau_{y z}+\varepsilon_{i}$

where

Yi: quantity corresponding to measure $\mathrm{i}$;

$\mathrm{a}_{1 \mathrm{i}}, \mathrm{a}_{2 \mathrm{i}}, \mathrm{a}_{3 \mathrm{i}}, \mathrm{a}_{4 \mathrm{i}}, \mathrm{a}_{5 \mathrm{i}}, \mathrm{a}_{6 \mathrm{i}}:$ coefficients depending of the geometry of the borehole, rock proprieties, and CSIRO cell characteristics; 
$\sigma_{\mathrm{x}}, \sigma_{\mathrm{y}}, \sigma_{\mathrm{z}}, \tau_{\mathrm{xy}}, \tau_{\mathrm{yz}}, \tau_{\mathrm{xz}}:$ natural stresses matrix according to fixed coordinates system (X: East, Y: North, and Z: the vertical);

$\varepsilon_{\mathrm{i}}:$ residual value estimated during the calculation.

For this reason, it is a question of quantifying the influence of each measure on the overall adjustment by introducing statistical indicators in the calculation:

The estimation of Yi is given by the following relationship:

$Y_{\text {estimated }}=A \cdot \sigma=\left|A \cdot\left(A^{\prime} \cdot A\right)^{-1}\right| . Y=H . Y$

where

A: quantity measured;

$\mathrm{A}^{\prime}$ : transposed form of the matrix $\mathrm{A}$;

Y: quantity measured.

In order to interpret the adjustment in a comprehensive way, three essential statistical indicators have been adopted. The first one is the residual standard deviation (RSD), which allows quantifying the difference between the measured and estimated values globally:

$R S D=\sqrt{\frac{\sum\left(Y_{i}-Y_{i(\text { estimated })}\right)^{2}}{n-p}}$

where

$\mathrm{n}$ : number of measures;

p: number of unknowns.

The second one is the reduced residue $r_{i}$ of the measure $i$ :

$r_{i}=\frac{Y_{i}-Y_{i(\text { estimated })}}{R S D \cdot \sqrt{1-h_{i i}}}$

where

$\mathrm{h}_{\mathrm{ii}}$ : diagonal term of the matrix $\mathrm{H}$ given in equation 13 .

The third one is the $\mathrm{D}$ of Cook defined by the following equation:

$D_{i}=\frac{r_{i}^{2} \cdot h_{i i}}{p \cdot\left(1-h_{i i}\right)}$

\section{METHODOLOGY}

At the beginning, to optimize the dip and dip direction of the borehole and the distribution of measurement gauges within the CSIRO cell, it is interesting to apply the "Surfrac" program in order to exploit the data resulting from in situ measurements. In fact, principal stresses tensor is calculated based on the displacements or strains and various in situ orientation measurements. Furthermore, for each measurement, the program calculates the coefficients $\mathrm{a}_{\mathrm{i}}$ linking the stresses to the measurements. In addition, theses coefficients depend on the characteristics of the rock medium, the orientation of the borehole, and the measurement itself. Moreover, once the coefficients are calculated, it is possible to make assumptions on the main stresses tensor. In this regard, we can impose a main direction, which makes the unknowns from six to four. If, in addition, the value of the stress is imposed in this direction, the unknowns go from four to three. However, the "Surfrac" program also makes it possible to eliminate certain measures, whether they 
have appeared dubious, or to have their influence on the result. In fact, there are two methods for solving the linear system: a combinatorial resolution and a statistical resolution (least squares method). In order to calculate the main stresses and their orientations, a global reference is necessary. Moreover, the program "Surfrac" is written in Pascal, FORTRAN, and is implemented on HP9000 series computers. In this sense, to optimize the dip and the dip direction of the borehole, it is necessary to vary the first from $0^{\circ}$ to $90^{\circ}$ and the second from $0^{\circ}$ to $360^{\circ}$. Moreover, the dip is calculated for each $10^{\circ}$, and the dip direction for each $30^{\circ}$ (Figure 4). Furthermore, to optimize the gauge in CSIRO cell compared to the dip direction of the borehole, it is interesting to vary the orientation of the gauge from $0^{\circ}$ to $180^{\circ}$ (orientation of the gauge compared to the borehole axis). Moreover, the orientation of the gauge is calculated for each $10^{\circ}$, and the dip direction of the borehole for each $30^{\circ}$ (Figure 3). Moreover, the optimization concerns all the twelve gauges adopted in the CSIRO cell and for this simulation, using the "Surfrac" program. Finally, in Figure 4, we present the flowchart concerning the procedure used to carry out the 3D modeling concerning the stresses and strains simulated within the model based on three scenarios, in which boundary conditions and CSIRO cell gauges are taken into consideration.

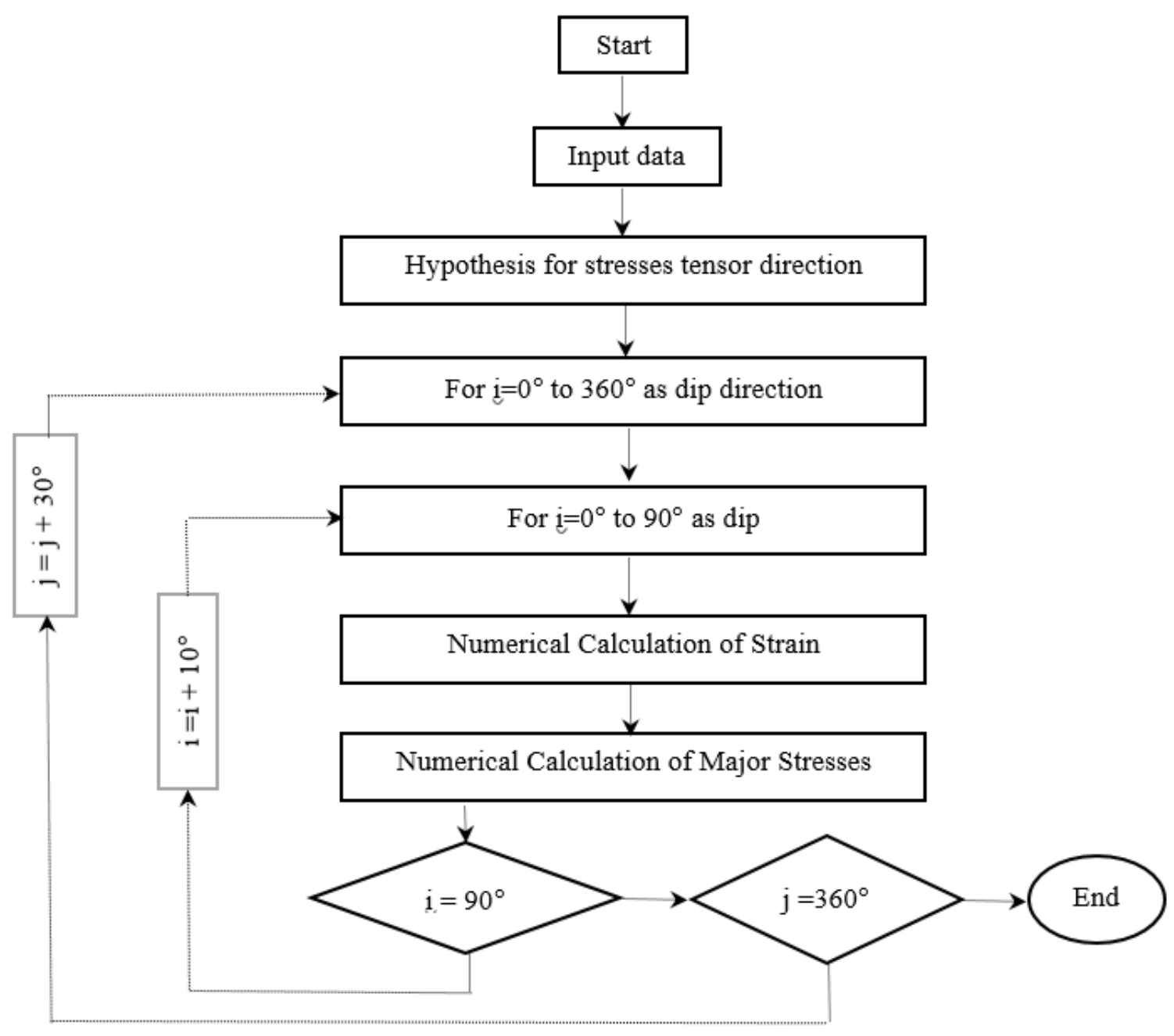

Figure 4. Flowchart of "Surfrac" program.

(Case of optimizing of the dip direction and the dip of borehole.) 


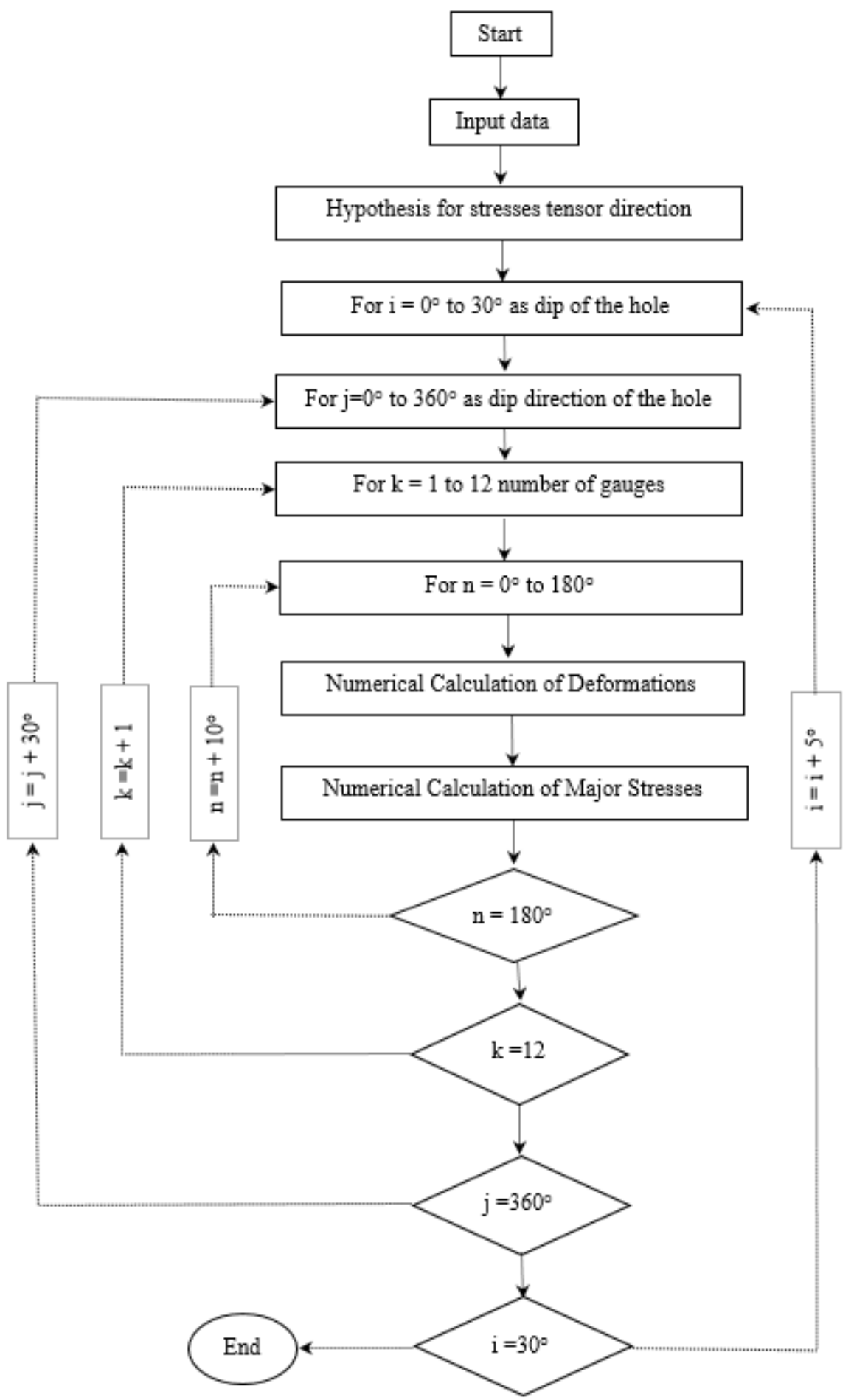

Figure 5. Flowchart of "Surfrac" program modified.

(Case of optimizing of the gauges of CSIRO cell.) 
(Case of optimizing of the gauges of CSIRO cell).

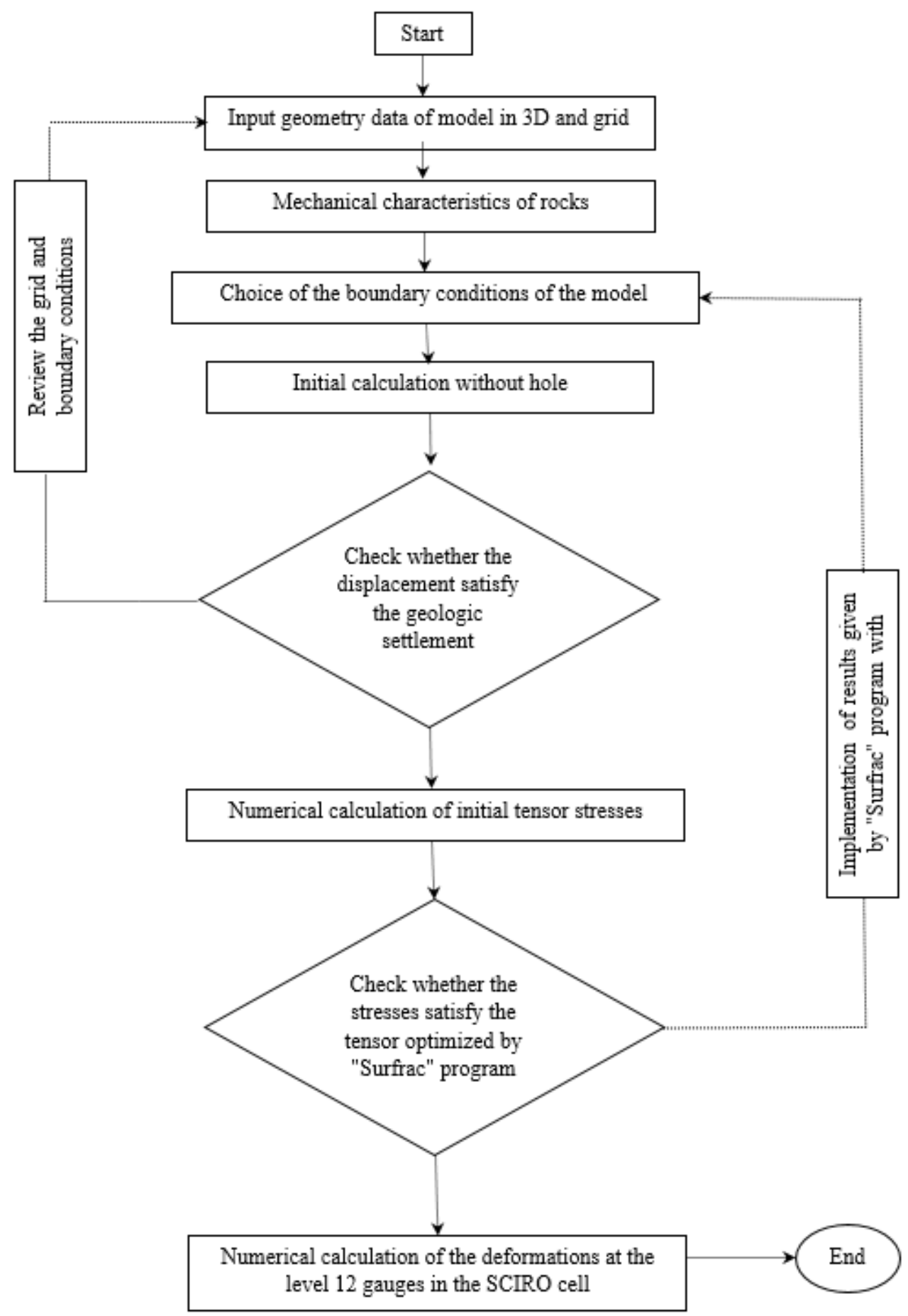

Figure 6. Flowchart of 3D modeling of stresses and strains using 12 gauges in the CSIRO cell in Abaqus software. 
Table 1. Geotechnical proprieties of rock mass according to the literature review.

\begin{tabular}{ccccccccc}
\hline Rock type & $\begin{array}{c}\gamma \\
\left(\mathbf{K g} / \mathbf{m}^{3}\right) \\
\text { Density }\end{array}$ & $\begin{array}{c}\mathbf{E}_{\perp} \\
(\mathbf{G P a})\end{array}$ & $\begin{array}{c}\mathbf{E}_{/ /} \\
(\mathbf{G P a})\end{array}$ & $\begin{array}{c}v_{\perp} \\
(-)\end{array}$ & $\begin{array}{c}v_{/ /} \\
(-)\end{array}$ & $\begin{array}{c}\mathbf{G} \\
(\mathbf{G P a})\end{array}$ & $\begin{array}{c}\mathbf{R}_{\mathbf{a n}}= \\
\mathbf{E}_{/ /} / \mathbf{E}_{\perp}\end{array}$ & Reference \\
\hline Sandstone & 2000 & 30 & 45 & 0.25 & 0.20 & 20 & 1.50 & (Ouanas, 2010) \\
\hline Limestone & 2500 & 50 & 60 & 0.30 & 0.28 & 25 & 1.20 & (Brady \& Brown, 2004) \\
\hline Granite & 4500 & 60 & 75 & 0.25 & 0.20 & 30 & 1.25 & (Ask, 2003) \\
\hline
\end{tabular}

$\mathbf{E}_{\perp}$ : Young's modulus perpendicular to rock stratum; $\mathbf{E}_{/ /}$: Young's modulus parallel to rock stratum; $v_{\perp}$ and $v_{/ /}$: Poisson's coefficients according to perpendicular and parallel rock stratum, respectively, and $\mathbf{R}_{\mathbf{a n}}$ : ratio of anisotropic Rock medium.
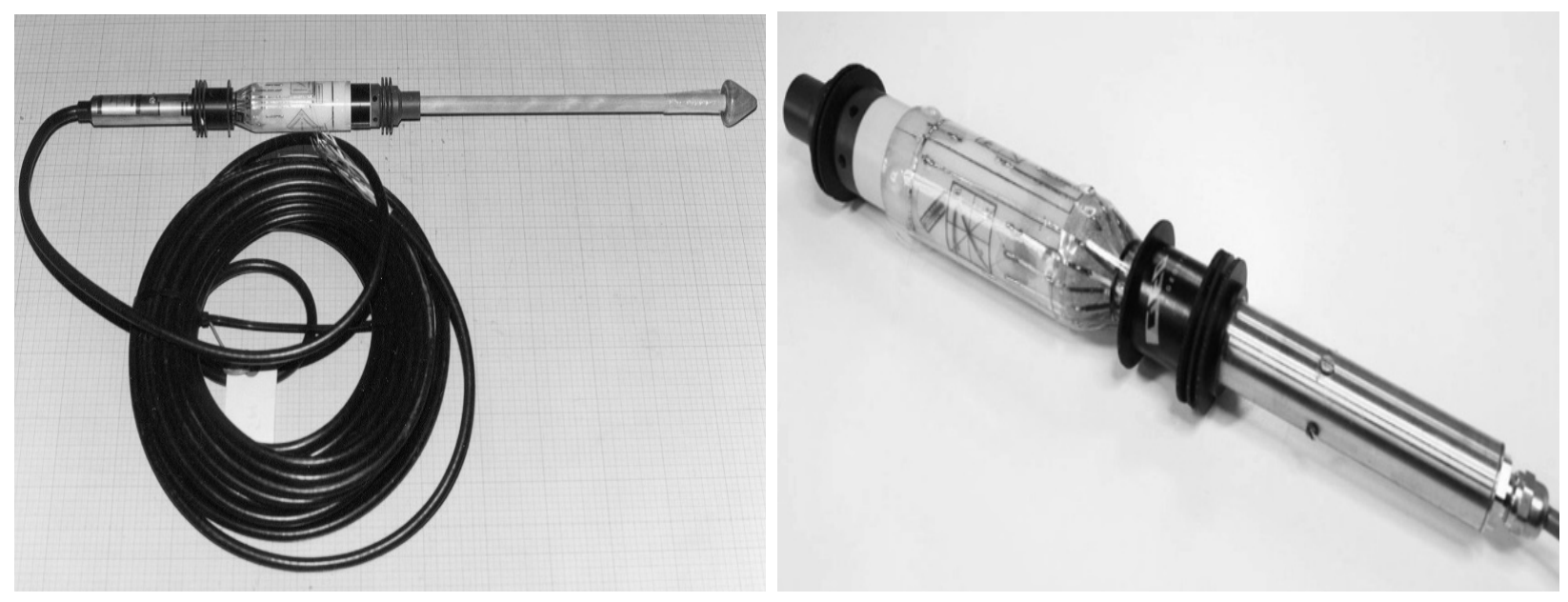

Figure 7. 3D Stresses CSIRO Analogue HI cell (CSIRO, 2019).

\section{RESULTS AND DISCUSSIONS}

In the beginning, we note that this applied research is purely theoretical. In fact, many factors can come into play for such a calculation (Khedher, 1992). In this sense, we supposed that the rock medium is considered as homogeneous and isotropic for the first phase. Thereafter, orthotropic medium and anisotropic medium are introduced in the 3D model. However, the geotechnical proprieties of rock mass as reference are adopted for the three scenarios proposed as parametric study concerning this numeric approach (Table 1). Firstly, based on the calculation carried out by "Surfrac" software, and using the least squares method, the statistical indicators for the exact measurements (Table 2 ), we recorded nonsignificant values concerning the residual difference, Cook's D and $H_{i i}$, respectively. Secondly, a further calculation was applied introducing error on one tangential gauge especially $n^{\circ} 09$, where there are significant values about residual difference, Cook's $\mathrm{D}$ and $\mathrm{H}_{\mathrm{i}}$, respectively (Table 3 ). In addition, it appears that an interval of $0^{\circ}$ to $30^{\circ}$ dipping of the borehole allows a better estimation of the natural stresses tensor. In addition, concerning the dip direction of the borehole compared with the major principal stress, two angles may be logical according to the calculation carried out in the first part, namely, $60^{\circ}$ and $90^{\circ}$. Furthermore, regarding the optimization of the gauges of CSIRO cell, it is necessary to give more importance to the axial gauges than to the tangential gauges. Indeed, according to the "Surfrac" program, it appears that, for an angle $90^{\circ}$, the residual standard deviation and the relative error on the shear stress in the general reference are acceptable in the two cases considered. Ultimately, "Surfrac" 
program allows calculating the major principal stresses tensor from the initial natural stresses tensor and estimates their dip and dipping direction referring to the general reference. In this regard, Table 4 illustrates the results where the dip and the dip direction of major stresses tensor are estimated for the exact measurements. Moreover, Table 5 shows the results where the dip and the dip direction of major stresses tensor are calculated with $10 \%$ error on the measure $n^{\circ} 09$. As a result, we found that there is no significant difference between the two cases on the orientation of the major principal stresses tensor. Furthermore, in order to see the dependence of the dip and the dip direction of the borehole as a function of the relative error on the strain measurements, for three cases (Figure 8), in fact, $10 \%$ of error is introduced for each type of gauge $\left(0^{\circ},\left(45^{\circ}\right.\right.$ and $\left.135^{\circ}\right)$ and $\left.90^{\circ}\right)$, where no significant difference is observed, but for the three cases, we prove that the low dip gives the low relative error value. In parallel, with the simulation carried out by "Surfrac" program, a 3D model was carried out based on Abaqus software in order to take into consideration the geometry of the borehole, in which the CSIRO cell is introduced. In addition, we take into account the boundary limits of the model, especially the state stresses, due to the tectonic movement of the study area. For this reason, three stresses tensors are applied for each simulation. Figure 9 illustrates the geometry of the 3D model, the grid density of each component, and the type of element chosen (tetrahedron). Moreover, the type of 3D element is chosen for the ring beside the 3D model, in which the introduced gauges of the CSIRO cell are illustrated in the same figure. However, for each scenario of modelling, many stages of simulation are adopted, starting by creating the grid model for each component from the boundary conditions until the ring, where the SCIRO cell elements are introduced. In fact, because of the high performance of the hardware used, the number of 3D elements, the number of nodes, and the time allocated to solve the 3D finite element matrix are illustrated in Table 6 . For this reason, in order to optimize the grid connectivity between each component of the 3D Model, many scenarios were carried out to converge to the typical model. In this regard, we found that the shapes of each strain gauge given by the 3D model using Abaqus software were identical to those registered in situ (Fouial et al., 1995; Ouanas, 2010). Moreover, according to Figure 10 for isotropic medium, we note that the tangential gauges give a clear difference in the value of strain compared to the axial gauges.

Table 2. Statistical indicators for the least squares method (exact measurements).

\begin{tabular}{ccccccc}
\hline $\mathbf{N}^{\circ}$ & Strain cal. & Strain est. & Diff. & Res. Diff. & Cook's D & $\mathbf{H}_{\text {ii }}$ \\
\hline 01 & $-1.761 \mathrm{E}-03$ & $-1.761 \mathrm{E}-03$ & $-1.164 \mathrm{E}-10$ & $-4.546 \mathrm{E}-01$ & $2.014 \mathrm{E}-02$ & $3.690 \mathrm{E}-01$ \\
02 & $-1.186 \mathrm{E}-03$ & $-1.186 \mathrm{E}-03$ & $2.3280 \mathrm{E}-10$ & $1.0570 \mathrm{E}+00$ & $2.130 \mathrm{E}-01$ & $5.334 \mathrm{E}-01$ \\
03 & $-1.163 \mathrm{E}-03$ & $-1.163 \mathrm{E}-03$ & $0.0000 \mathrm{E}+00$ & $0.0000 \mathrm{E}+00$ & $0.000 \mathrm{E}+00$ & $5.200 \mathrm{E}-01$ \\
04 & $-1.894 \mathrm{E}-03$ & $-1.894 \mathrm{E}-03$ & $0.0000 \mathrm{E}+00$ & $0.0000 \mathrm{E}+00$ & $0.000 \mathrm{E}+00$ & $5.560 \mathrm{E}-01$ \\
05 & $-1.696 \mathrm{E}-03$ & $-1.696 \mathrm{E}-03$ & $3.4920 \mathrm{E}-10$ & $1.6030 \mathrm{E}+00$ & $5.098 \mathrm{E}-01$ & $5.434 \mathrm{E}-01$ \\
06 & $-1.922 \mathrm{E}-03$ & $-1.922 \mathrm{E}-03$ & $2.3280 \mathrm{E}-10$ & $1.0810 \mathrm{E}+00$ & $2.419 \mathrm{E}-01$ & $5.538 \mathrm{E}-01$ \\
07 & $-1.761 \mathrm{E}-03$ & $-1.761 \mathrm{E}-03$ & $-1.164 \mathrm{E}-10$ & $-4.546 \mathrm{E}-01$ & $2.014 \mathrm{E}-02$ & $3.690 \mathrm{E}-01$ \\
08 & $-1.239 \mathrm{E}-03$ & $-1.239 \mathrm{E}-03$ & $-2.328 \mathrm{E}-10$ & $-1.026 \mathrm{E}+00$ & $1.784 \mathrm{E}-01$ & $5.043 \mathrm{E}-01$ \\
09 & $-1.815 \mathrm{E}-03$ & $-1.815 \mathrm{E}-03$ & $3.4920 \mathrm{E}-10$ & $1.8890 \mathrm{E}+00$ & $1.214 \mathrm{E}+00$ & $6.711 \mathrm{E}-01$ \\
10 & $-1.784 \mathrm{E}-03$ & $-1.784 \mathrm{E}-03$ & $2.3280 \mathrm{E}-10$ & $9.9060 \mathrm{E}-01$ & $1.440 \mathrm{E}-01$ & $4.683 \mathrm{E}-01$ \\
11 & $-1.712 \mathrm{E}-03$ & $-1.712 \mathrm{E}-03$ & $-3.492 \mathrm{E}-10$ & $-1.486 \mathrm{E}+00$ & $3.246 \mathrm{E}-01$ & $4.686 \mathrm{E}-01$ \\
12 & $-9.764 \mathrm{E}-04$ & $-9.764 \mathrm{E}-04$ & $-1.164 \mathrm{E}-10$ & $-4.840 \mathrm{E}-01$ & $3.109 \mathrm{E}-02$ & $4.432 \mathrm{E}-01$ \\
\hline
\end{tabular}

Strain cal.: Strain calculated; Strain est.: Strain estimated; Diff.: Difference; Res. Diff.: Residual Difference; 
$\mathbf{H}_{\mathrm{ii}}$ : Diagonal term of the matrix H (see the equation 15).

Table 3. Statistical indicators for the least squares method ( $10 \%$ error on measure $\left.n^{\circ} 09\right)$.

\begin{tabular}{ccccccc}
\hline $\mathbf{N}^{\circ}$ & Strain cal. & Strain est. & Diff. & Res. Diff. & Cook's D & $\mathbf{H}_{\text {ii }}$ \\
\hline 01 & $-1.800 \mathrm{E}-03$ & $-1.810 \mathrm{E}-03$ & $-1.0470 \mathrm{E}-05$ & $3.7940 \mathrm{E}-01$ & $1.403 \mathrm{E}-02$ & $3.690 \mathrm{E}-01$ \\
02 & $-1.143 \mathrm{E}-03$ & $-1.138 \mathrm{E}-03$ & $-5.0400 \mathrm{E}-06$ & $-2.120 \mathrm{E}-01$ & $8.591 \mathrm{E}-03$ & $5.334 \mathrm{E}-01$ \\
03 & $-1.495 \mathrm{E}-03$ & $-1.463 \mathrm{E}-03$ & $-3.1700 \mathrm{E}-05$ & $-1.320 \mathrm{E}+00$ & $3.143 \mathrm{E}-01$ & $5.200 \mathrm{E}-01$ \\
04 & $-1.795 \mathrm{E}-03$ & $-1.765 \mathrm{E}-03$ & $-2.9900 \mathrm{E}-05$ & $-1.290 \mathrm{E}+00$ & $3.494 \mathrm{E}-01$ & $5.560 \mathrm{E}-01$ \\
05 & $-1.826 \mathrm{E}-03$ & $-1.858 \mathrm{E}-03$ & $3.1430 \mathrm{E}-05$ & $1.339 \mathrm{E}+00$ & $3.557 \mathrm{E}-01$ & $5.434 \mathrm{E}-01$ \\
06 & $-1.918 \mathrm{E}-03$ & $-1.914 \mathrm{E}-03$ & $-3.8800 \mathrm{E}-06$ & $-1.670 \mathrm{E}-01$ & $5.773 \mathrm{E}-03$ & $5.538 \mathrm{E}-01$ \\
07 & $-1.800 \mathrm{E}-03$ & $-1.810 \mathrm{E}-03$ & $1.0470 \mathrm{E}-05$ & $3.7940 \mathrm{E}-01$ & $1.403 \mathrm{E}-02$ & $3.690 \mathrm{E}-01$ \\
08 & $-1.194 \mathrm{E}-03$ & $-1.208 \mathrm{E}-03$ & $1.4060 \mathrm{E}-05$ & $5.7520 \mathrm{E}-01$ & $5.610 \mathrm{E}-02$ & $5.043 \mathrm{E}-01$ \\
09 & $-1.631 \mathrm{E}-03$ & $-1.583 \mathrm{E}-03$ & $-4.8800 \mathrm{E}-05$ & $-2.450 \mathrm{E}+00$ & $2.041 \mathrm{E}+00$ & $6.711 \mathrm{E}-01$ \\
10 & $-1.448 \mathrm{E}-03$ & $-1.485 \mathrm{E}-03$ & $3.7170 \mathrm{E}-05$ & $1.4680 \mathrm{E}+00$ & $3.163 \mathrm{E}-01$ & $4.683 \mathrm{E}-01$ \\
11 & $-1.693 \mathrm{E}-03$ & $-1.702 \mathrm{E}-03$ & $8.4710 \mathrm{E}-06$ & $3.3470 \mathrm{E}-01$ & $1.646 \mathrm{E}-02$ & $4.686 \mathrm{E}-01$ \\
12 & $-9.188 \mathrm{E}-04$ & $-9.261 \mathrm{E}-04$ & $7.3090 \mathrm{E}-06$ & $2.8210 \mathrm{E}-01$ & $1.056 \mathrm{E}-02$ & $4.432 \mathrm{E}-01$ \\
\hline
\end{tabular}

Strain cal.: Strain calculated; Strain est.: Strain estimated; Diff.: Difference; Res. Diff.: Residual Difference; $\mathbf{H}_{\mathrm{ii}}$ : Diagonal term of the matrix $\mathrm{H}$ (see the equation 15).

Table 4. Stresses dip direction and dip for exact measurements.

\begin{tabular}{cccccc}
\hline Stresses & Values (MPa) & St. Dev. & Student & Dip direction $\left(^{\circ}\right)$ & Dip $\left(^{\circ}\right.$ ) \\
\hline$\sigma_{\mathrm{x}}$ & 19.540 & $2.158 \mathrm{E}-06$ & $9.053 \mathrm{E}+06$ & - & - \\
$\sigma_{\mathrm{y}}$ & 22.450 & $2.759 \mathrm{E}-06$ & $8.137 \mathrm{E}+06$ & - & - \\
$\sigma_{\mathrm{z}}$ & 12.010 & $1.895 \mathrm{E}-06$ & $6.338 \mathrm{E}+06$ & - & - \\
$\tau_{\mathrm{xy}}$ & 02.630 & $1.451 \mathrm{E}-06$ & $1.811 \mathrm{E}+06$ & - & - \\
$\tau_{\mathrm{yz}}$ & 00.190 & $1.811 \mathrm{E}-06$ & $1.036 \mathrm{E}+05$ & - & - \\
$\tau_{\mathrm{zx}}$ & -00.090 & $1.419 \mathrm{E}-06$ & $-6.590 \mathrm{E}+04$ & - & - \\
$\sigma_{1}$ & 24.000 & - & - & 30 & 0.6 \\
$\sigma_{2}$ & 18.000 & - & - & 300 & 1.7 \\
$\sigma_{3}$ & 12.000 & - & - & 138 & 88 \\
\hline
\end{tabular}

St. Dev.: Standard Deviation; Student: Statistical student table coefficient. 
Table 5. Stresses dip direction and dip for $10 \%$ error on measure $n^{\circ} 09$.

\begin{tabular}{cccccc}
\hline Stresses & Values (MPa) & St. Dev. & Student & Dip direction $\left({ }^{\circ}\right)$ & Dip $\left(^{\circ}\right)$ \\
\hline$\sigma_{\mathrm{x}}$ & 19.820 & $1.774 \mathrm{E}-01$ & $1.117 \mathrm{E}+02$ & - & - \\
$\sigma_{\mathrm{y}}$ & 22.290 & $2.268 \mathrm{E}-01$ & $9.830 \mathrm{E}+01$ & - & - \\
$\sigma_{\mathrm{z}}$ & 12.080 & $1.558 \mathrm{E}-01$ & $7.754 \mathrm{E}+01$ & - & - \\
$\tau_{\mathrm{xy}}$ & 02.820 & $1.192 \mathrm{E}-01$ & $2.364 \mathrm{E}+01$ & - & - \\
$\tau_{\mathrm{yz}}$ & -00.110 & $1.488 \mathrm{E}-01$ & $-7.170 \mathrm{E}-01$ & - & - \\
$\tau_{\mathrm{zx}}$ & -00.340 & $1.166 \mathrm{E}-01$ & $-2.913 \mathrm{E}+00$ & - & - \\
$\sigma_{1}$ & 24.000 & - & - & 210 & 1.3 \\
$\sigma_{2}$ & 18.000 & - & - & 303 & 2.2 \\
$\sigma_{3}$ & 12.000 & - & - & 92 & 87 \\
\hline
\end{tabular}

St. Dev.: Standard Deviation; Student: Statistical student table coefficient.

Furthermore, for orthotropic medium, the strain values become significant, especially perpendicular to major principal stress and for the same gauges (Figure 11). Finally, for anisotropic medium with high values of natural stresses tensor, the tangential strain gauges present the biggest strain values (Figure 12). As a conclusion, this 3D model shows that the tangential gauges within CSIRO cell provide significant strain values compared to axial gauges. In addition, the in situ results given by the CSIRO cell in many sites around the world prove that it is interesting to validate this method for the site of southern province in Saudi Arabia. Moreover, 3D modeling involves the discontinuities network observed in the study area recommended.
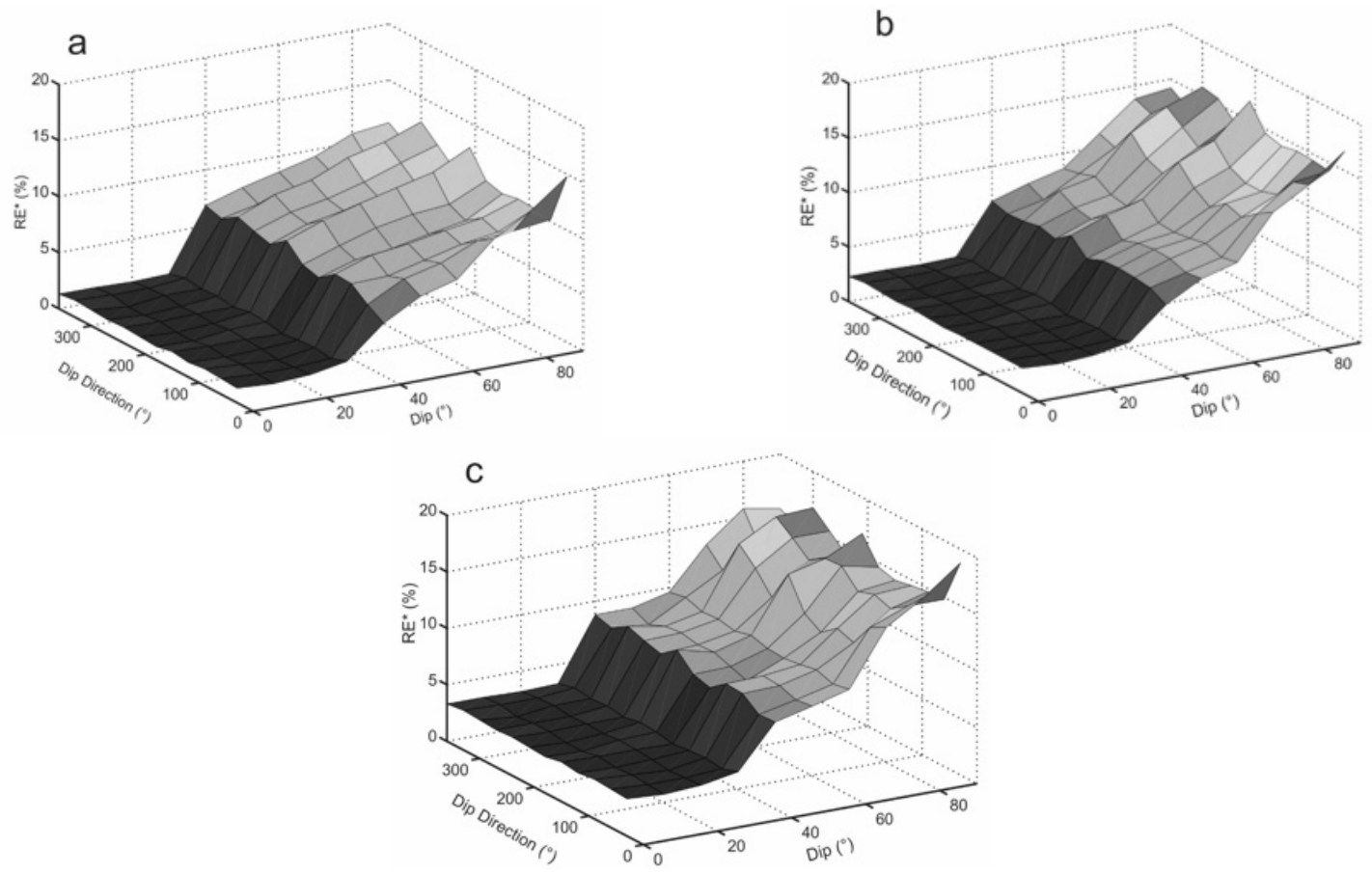

Figure 8. 3D curves to optimize the dip and the dip direction of the borehole.

(a: Error of $10 \%$ Gauge $90^{\circ}$; b: Error of $10 \%$ Gauge $45^{\circ} \& 135^{\circ}$; c: Error of $10 \%$ Gauge $0^{\circ}$; ${ }^{*} \mathbf{R E}$ : Relative Error.) 

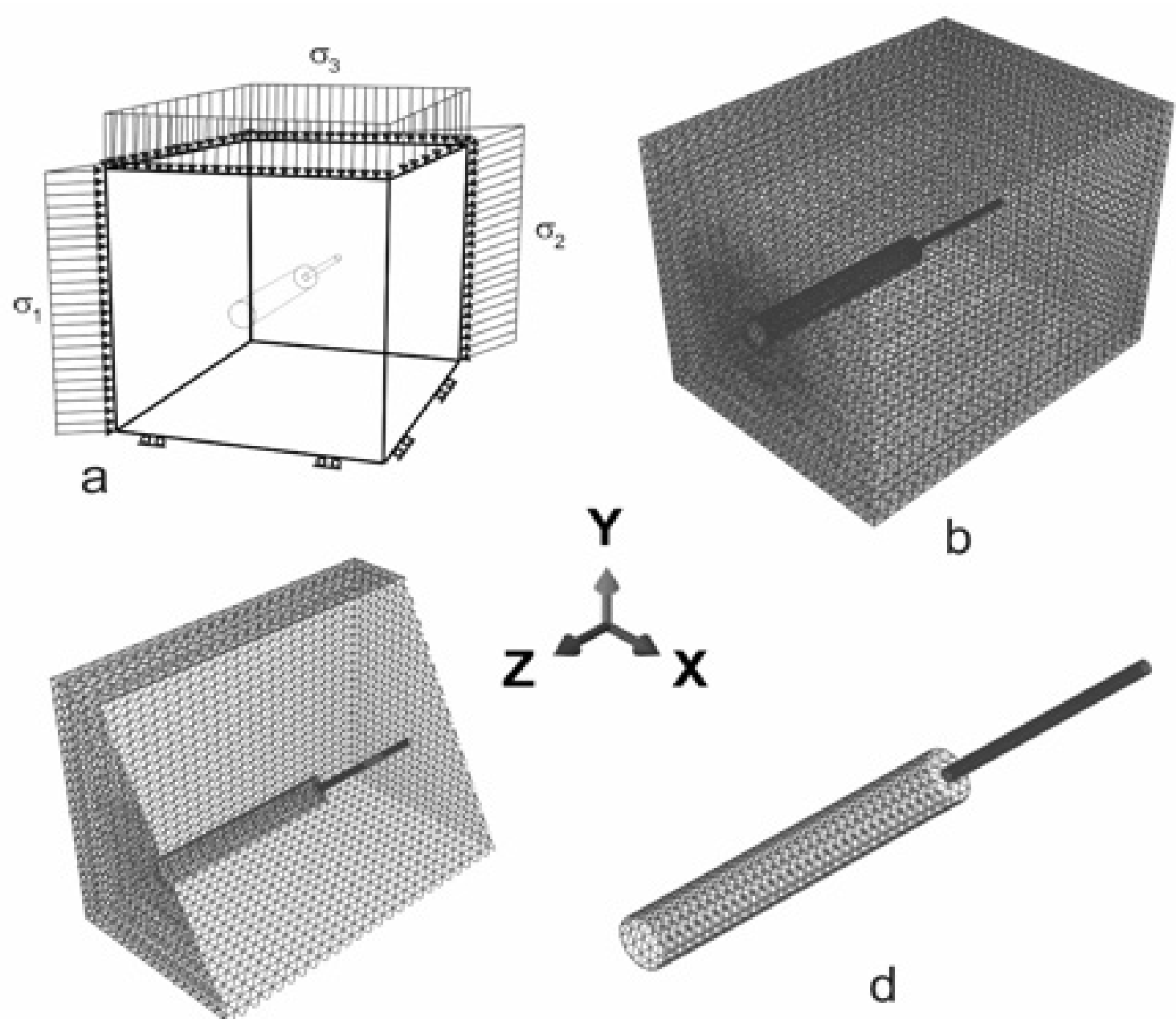

C
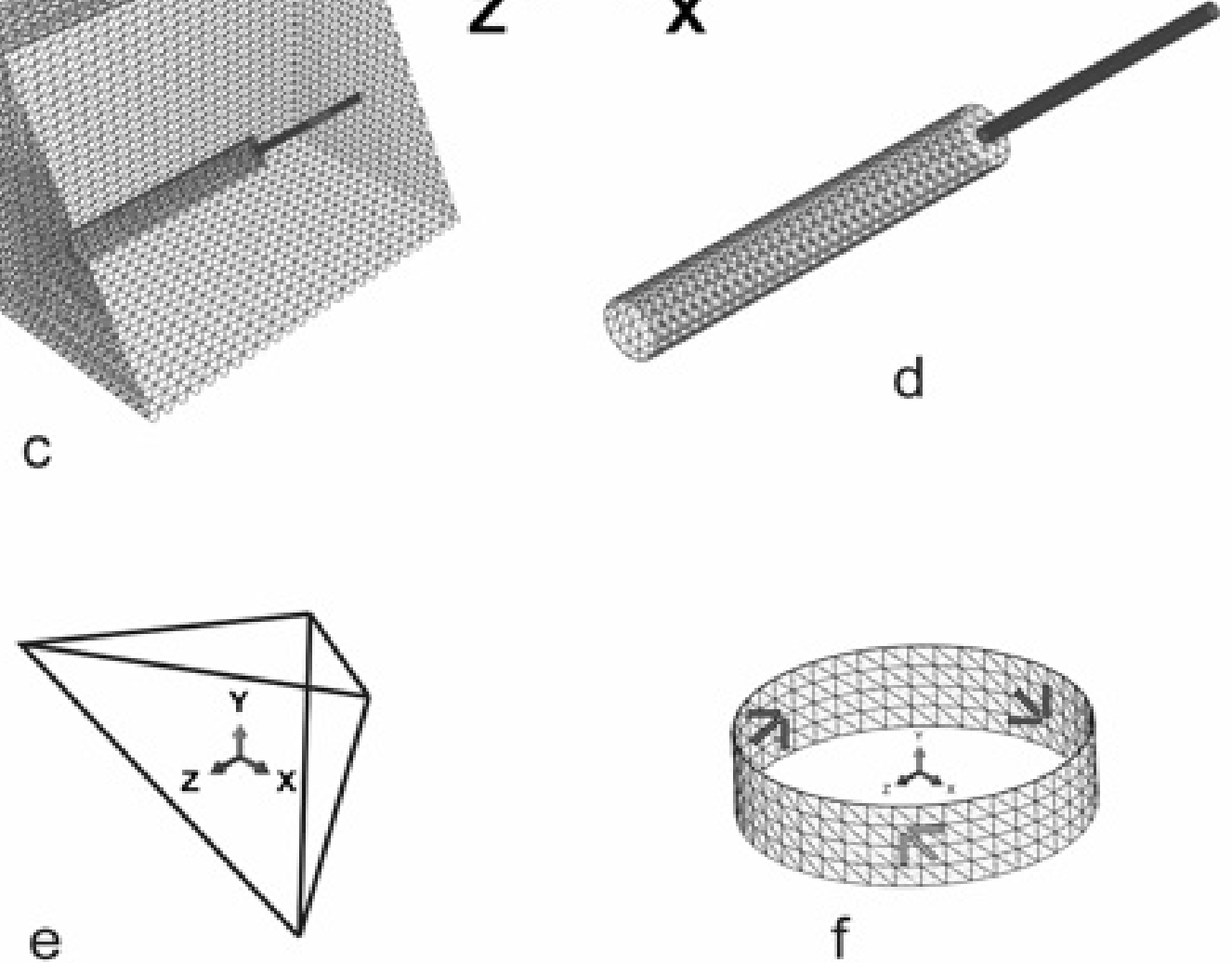

Figure 9. 3D model proposed for CSIRO cell.

(a: Boundary conditions; b: 3D Model grid; c: Cross-section in 3D Model grid; d: Borehole 3D model grid; e: 3D Grid element: tetrahedron; f: Ring in which gauge introduced in the 3D Model.) 
Table 6. Characteristics of the 3D model adopted for Abaqus simulation.

\begin{tabular}{lccc}
\hline Phase & 3D Elements* Number & Nodes & Time allocated (sec) \\
\hline Initial bloc & 140211 & 197785 & 3000 \\
First hole & 119180 & 168118 & 4500 \\
Second hole & 105158 & 148273 & 5500 \\
Overcoring with cell & 105158 & 148273 & 3500 \\
SCIRO Cell gauges & 250 & 350 & 5600 \\
\hline
\end{tabular}

*Tetrahedron element (Figure 6e).

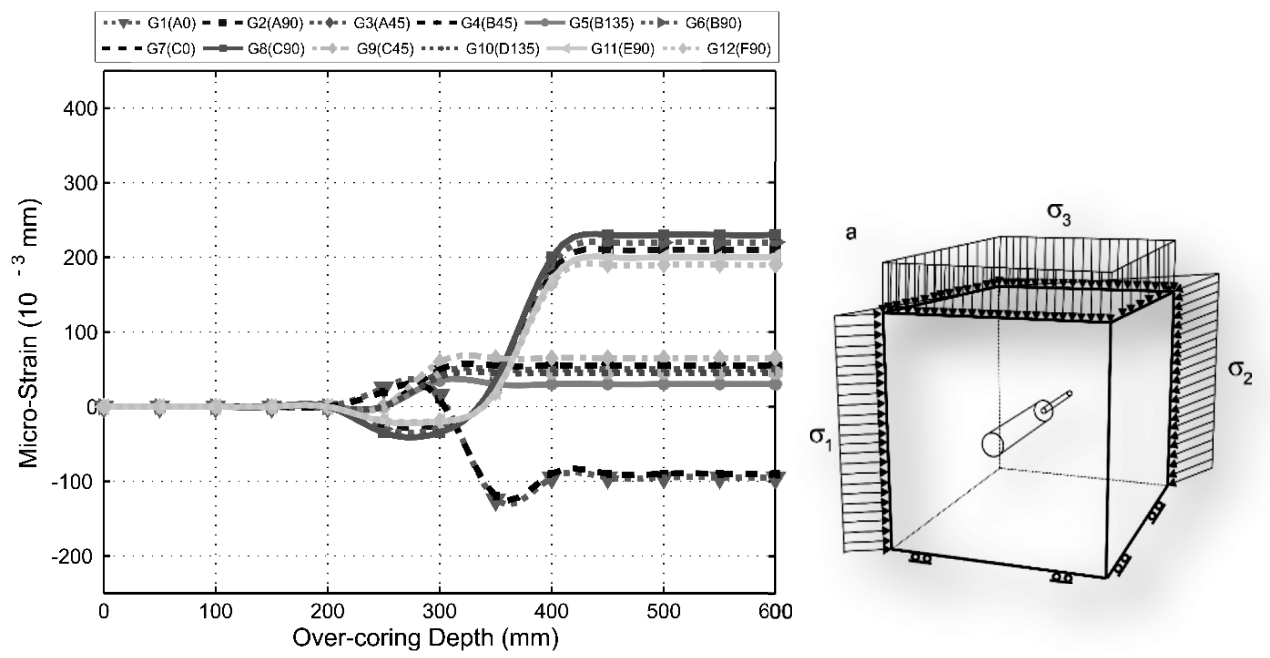

Figure 10. Micro-strain estimated in the 3D Model for Major Principal Stress.
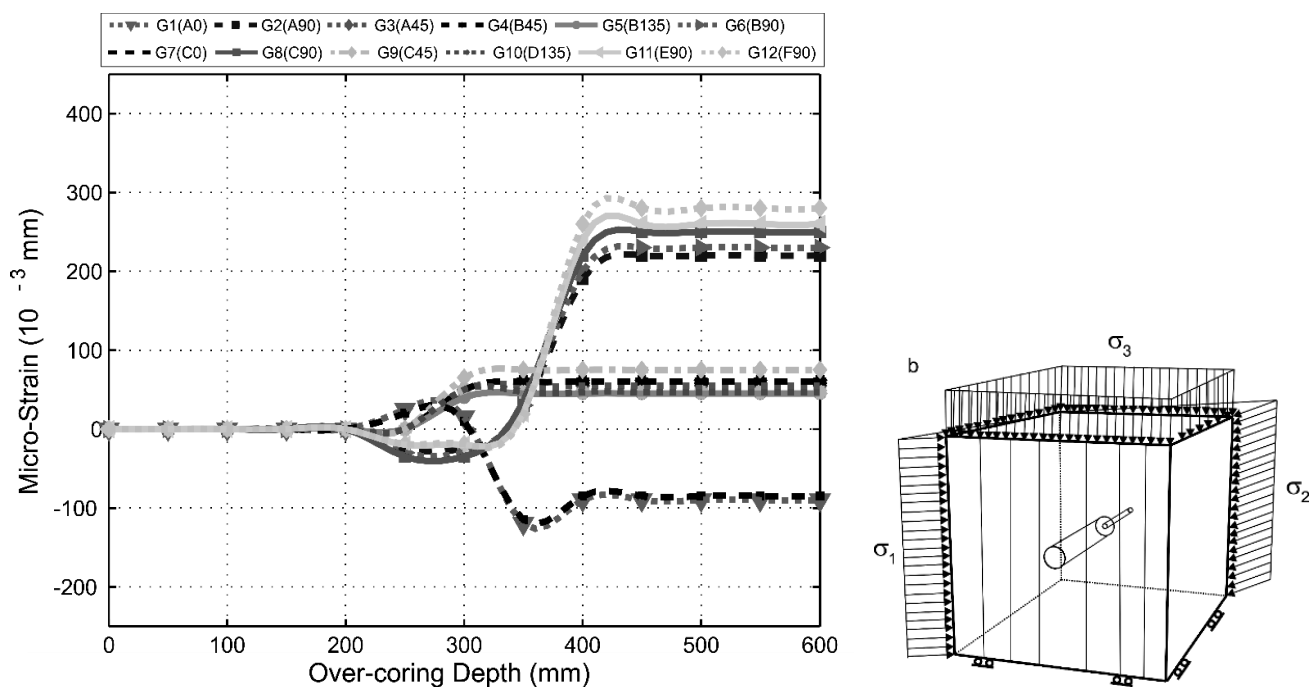

Figure 11. Micro-strain estimated in the 3D Model for Major Principal Stress. (b: Orthotropic medium: $\sigma_{1}=100 \mathrm{MPa} ; \sigma_{1}=50 \mathrm{MPa} ; \sigma_{1}=25 \mathrm{MPa}$.) 

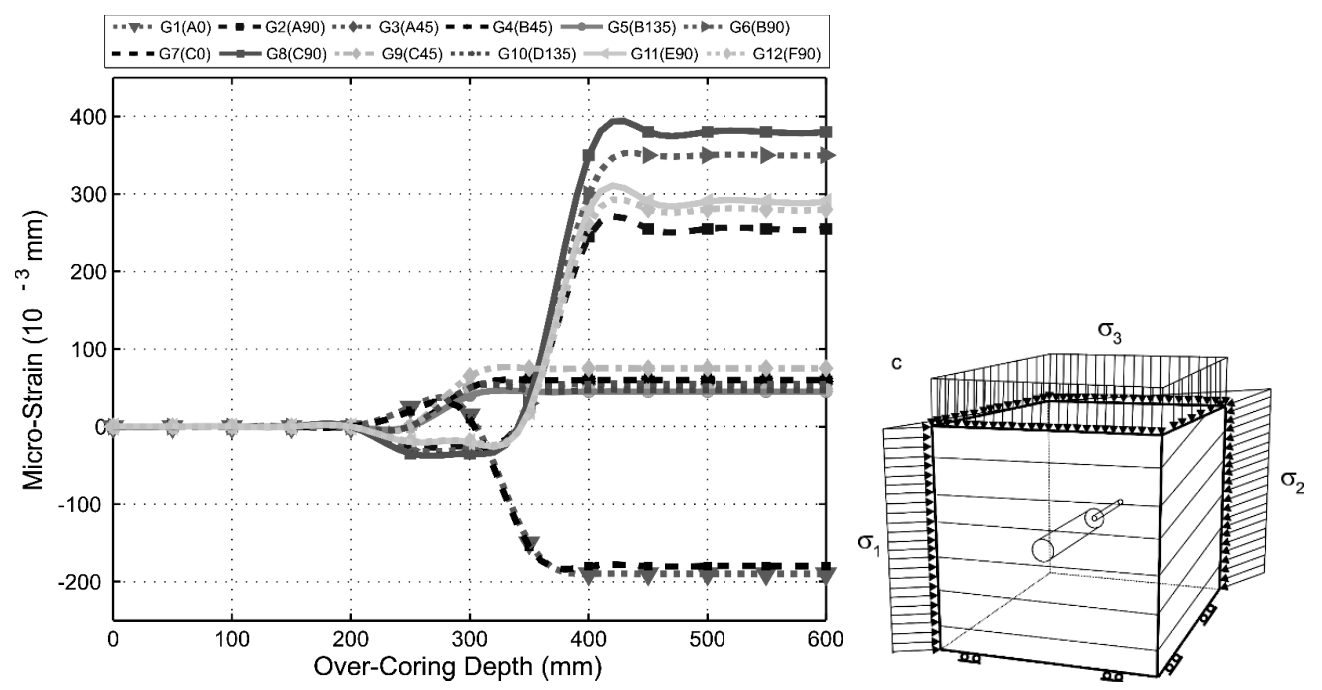

Figure 12. Micro-strain estimated in the 3D Model for Major Principal Stress.

(c: Anisotropic medium: $\sigma_{1}=200 \mathrm{MPa} ; \sigma_{1}=100 \mathrm{MPa} ; \sigma_{1}=50 \mathrm{MPa}$.)

\section{CONCLUSIONS}

As a conclusion, it should be noted here that this research deals with the theory of stresses and deformations within the isotropic and anisotropic rock masses. In addition, this research focuses on the possibility of measuring the stresses and deformations based on 3D CSIRO cell in order to optimize the dip direction of the hole and to optimize the orientation of the gauges within the 3D CSIRO cell. However, referring to the numerical calculation carried out by the program "Surfrac," we have chosen that the dip of the measuring hole must not exceed the value of $30^{\circ}$ in an isotropic medium. Moreover, regarding the dip direction of the hole with respect to the dip direction of the major principal stress $\left(\sigma_{1}\right)$, two angles can be acceptable according to the computation carried out. Furthermore, concerning the optimization of the 12 gauges of the CSIRO cell, it is clear from the calculations that we must give more importance to the tangential gauges than those axial ones. On the other hand, a three-dimensional numerical model was carried out to understand the effect of the anisotropy on the orientation of the gauges of measurement within the SCIRO cell. In this context, we have developed a program named "Surfrac" (initially developed within the Mechanical Terrain Laboratory at the National High School of Mines in Nancy), currently part of the University of Lorraine. In fact, the strain of each gauge in the CSIRO cell has been simulated using the 3D model performed by Abaqus software. In the same way, the 3D modeling confirms the idea that less than $30^{\circ}$ dip of the hole relative to the horizontal is acceptable, in the best case, equal to $20^{\circ}$. On the other hand, a dip direction of the borehole perpendicular to the dip direction of rock layers favors the work of the axial gauges; on the contrary, the hole parallel to the stratification favors the tangential one. Regarding the dip direction of the hole, with respect to the dip direction of the major principal stress $\left(\sigma_{1}\right)$, two angles can be acceptable according to the computation carried out. Furthermore, concerning the optimization of the 12 gauges of the CSIRO cell, it is clear from the calculations that we must give more importance to the tangential gauges than those axial ones. As a result, the main findings of this research are summarized in three points: the first is dealing with the CSIRO cell itself, where the direction of the gauge is important during the measurement of stresses; in fact, the perpendicular gauges work better than the ones parallel to the hole axis. The second one is that it is evident from the model that the direction of hole must be perpendicular to the dip direction of the rock layers, allowing to give better results compared to others. The third one is that the selection of the measurement site requires involving the regional stresses of the study area according to geological investigation. Finally, it is interesting to carry out geophysical exploration in the study area to understand the local tectonic movement of rock masses. Moreover, a detailed map can be used to highlight the main fractures and faults network and overlap it with the most important projects deployed in Aseer province for maintenance and monitoring. 


\section{RECOMMENDATIONS \& FUTURE WORK}

Through this numerical approach, the research team proved the importance of applying the theoretical aspect by working on the design of overcoring CSIRO cell. Furthermore, the dip direction of the borehole compared to the dip direction of the rock stratum and the network of fractures and faults is very important in measuring the stresses within the rock masses. Moreover, it is necessary to investigate the Aqabat Al-Sulbat road study area in Aseer province in point of view geological and geophysical conditions in order to provide an accurate map about the distribution of the regional stresses in the same study site. For this reason, we intend to work closely with specialists and researchers in geology and geophysics from other Saudi universities. In addition, to verify the dip direction of the regional stresses in the study area, additional 3D numerical modeling that takes into account fractures and faults network in the study site must be considered to understand the tectonic of rocks close the major projects and its impact on them on the long term. Finally, in the framework of applied research supported by King Khalid University in Abha, the research team is working on creating the Rock Mechanics and Applied Geophysics Laboratory. In this context, all equipment and devices, such as CSIRO cell and software, should be acquired to achieve the tasks of in situ rock stresses, measuring and inspecting the state rock nearby the major Civil Engineering projects in Aseer province. Moreover, we validate this numerical approach, and it prevents against the rock fall observed, usually, on both sides of the main roads and close to the new residential urban planning.

\section{ACKNOWLEDGMENT}

The research team appreciates the efforts of King Khalid University in financing this applied research and providing all the facilities (laboratories, hardware, and software) in the College of Engineering. In addition, special thanks are due to the Civil Engineering Department, where this applied research work was achieved. Finally, thanks again are due to the Deanship of Scientific Research in King Khalid University for supporting this research work (G.R.P. $305-40$ ).

\section{REFERENCES}

Amadei, B., 1996. Importance of anisotropy when estimating and measuring in situ stresses in rock. Int. J. Rock Mech. Min. Sci. \& Geomech. Abstr. 33: 293-325.

Amadei, B., Pan, E., 1992. Gravitational Stresses in Anisotropic Rock Masses with Inclined Strata. Int. J. Rock Mech. Min. Sci. \& Geomech. Abstr. 29: 225-236.

Amadei, B., 1984. In situ stress measurements in anisotropic rock. Int. J. Rock Mech. Min. Sci. \& Geomech. Abstr. 21: 327-338.

Amadei, B. \& Stephansson, O. 1997. Rock Stress and Its Measurement. Chapman \& hall. UK pp.490.

Amadei, B., 1986. Analysis of data obtained with the CSIRO cell in anisotropic rock masses. CSIRO Division of Geo-mechanics, Technical Report No. 141

Amadei, B., Savage, W.Z. \& Swolfs, H.S., 1987. Gravitational stresses in anisotropic rock masses. Int. J. Rock Mech. Min. Sci. \& Geomech. Abstr. 24: 5-14.

Amadei, B., Swolfs, H.S. \& Savage, W.Z., 1988. Gravity induced stresses in stratified rock masses. Rock Mech. 21: 1-20.

Amadei, B. \& Savage, W.Z., 1985. Gravitational stresses in regularly jointed rock masses. Proc. Int. Symp. On Fundamentals of Rock Joints, Bjorkliden, Sweden. pp. 463-473.

Amadei, B., 1985. Applicability of the theory of hollow inclusions of over-coring stress measurements in rock. Rock Mech. Rock Eng. 18: 107-130.

Amadei, B., 1983. Rock Anisotropy and the Theory of Stress Measurements, Lecture Notes in Engineering Series. Springer, New York.

Aseer Municipality, 2020a. Geotechnical Site Investigation for Aqabat Al-Sulbat - Landslide. Internal Report 285 p.

Aseer Municipality, 2020b. Analytical Interpretations of the Geotechnical Field Data and Design Civil Engineering works. Internal Report $32 \mathrm{p}$. 
Aseer Municipality, 2020c. 3D Assessment of Aqabat Al-Sulbat Road Section. Hydrolog, King Abdullah University of Science and Technology. Internal Report $15 \mathrm{p}$.

Ask, D., 2003. Evaluation of measurement-related uncertainties in the analysis of over-coring rock stress data from Aspo HRL, Sweden: a case study. Int. J. Rock Mech. \& Min. Sciences, 40: 1173-1187.

Baroudi, H. \& Revalor R., 1994. Descriptive of technical measurement of stresses. Over-coring method, following the stresses evolution. Training Seminar CEEC (COMETT program), solicitations and stresses measurement within the works and terrain, Mining High National School of Nancy.

Bosworth, W., Huchon, P. \& McClay, K., 2005. The Red Sea and the Gulf of Aden basins. J. Afr. Earth Sci., 43: 334-378.

Brady, B.H.G. \& Brown E.T., 2004. Rock Mechanics for underground Mining. Kluwer Academic Publishers Dordrecht / Boston / London. Third Edition, ISBN 1-4020-2064-3, pp. 628.

Brady, B.H.G, Lemos, J.V. \& Cundall, P.A., 1986. Stress measurement schemes for jointed and fractured rock, in Proc. Int. Symp. On Rock Stress and Rock Stress Measurements, Stockholm, Centek, Publ, Lulea, 99: 167-176.

Brady, E.T., Bray, J.W. \& Santarelli, F.J., 1989. Influence of stress dependent elastic moduli on stresses and strains around axisymmetric borehole. Rock Mech. Rock Eng. 22: 189-203.

Cai, M., 1990. Comparative tests and studies of over-coring stress measurement devices in different rock conditions, unpublished $\mathrm{PhD}$ Thesis, University of New South Wales, Australia.

Cai, M. \& Blackwood, R.L., 1991. A technique for the recovery and re-use of CSIRO hollow inclusion cells. Int. J. Rock Mech. Min. Sci. \& Geomech. Abstr. 28: 225-229.

Cai, M., Qiao, L. \& Yu, J., 1995. Study and tests of techniques for increasing over-coring stress measurement accuracy. Int. J. Rock Mech. Min. Sci. \& Geomech. Abstr. 32: 375-384.

Cai, M., Qiao, L., Li, C., Vu, B., Yu, B. \& Chen, G., 1995. Application of an Improved Hollow Inclusion Technique for in situ Stress Measurement in Xincheng Gold Mine, China. Int. J. Rock Mech. \& Min. Sci., 32: 735-739.

Chambon, C. \& Revalor, R., 1986. Statistical analysis applied to rock stress measurements, in Proc. Int. Symp. On Rock Stress and Rock Stress Measurements, Stockholm, Centek Publ. Lulea, pp. 397-410.

Chandler, N.A., 1993. Bored raise over-coring for in situ stress determination at the Underground Research Laboratory. Int. J. Rock Mech. Min. Sci. \& Geomech. Abstr. 30: 989-992.

Chikhaoui, M., 2009. Numeric simulation for determining in situ stresses within elastoplastic medium - 3D modeling, Master degree thesis in Civil Engineering. Specialty: Geotechnical Engineering. LEEGO laboratory - College of Civil Engineering USTHB - Beb Ezzouar Alger, Algeria.

CSIRO, 2019. Commonwealth Scientific and Industrial Research Organization, 3D Stresses CSIRO Analogue HI Cell user guide, Australia (http://www.essearth.com).

Deif, A., Al-Shijbi, Y., El-Hussain, I., Ezzelarab, M. \& Mohamed, A.M.E, 2017. Compiling an earthquake catalogue for the Arabian Plate, Western Asia, J. Asian Earth Sci., 147: 345-375.

El-Hussain, I., Al-Shijbi, Y., Deif, A., Mohamed, A.M.E. \& Ezzelarab, M., 2018. Developing a seismic source model for the Arabian Plate. Arabian Journal of Geosciences, 11: 435.

Fouial, K., Alheib, M., Baroudi, H. \& Trentsaux, C., 1998. Improvement in the interpretation of stress measurements by use of the over-coring method: development of a new approach. Engineering Geology, 49: 239-252.

Fouial, K., 1997. New method for interpretation of stresses measurement using over-coring method adopted for rock masses with fractured or nonlinear behavior. PhD Thesis in Lorraine University, INPL, pp. 217.

Gerrard, C.M., 1975. Background to mathematical modelling in geo-mechanics: the role of fabric and stress history. Proc. Int. Symp. On Numerical Methods, Karlsruhe, pp. 33-120.

Giot, R., Giraud, A. \& Homand, F., 2006. Three-Dimensional Finite Element Modelling of Stress Relaxation Tests in Anisotropic Clayey Medium: Direct Problem and Back Analysis. Geotechnical and Geological Engineering, 24: 919-947.

Goodman, R.E., 1980. Introduction to Rock Mechanics. Wiley. New York. 
Gomez, F., Karam, G., Khawlie, M, McClusky, S., Vernant, P., Reilinger, R., Jaafar, R., Tabet, C., Khair, K., \& Barazangi, M., 2007. Global Positioning System measurements of strain accumulation and slip transfer through the restraining bend along the Dead Sea fault system in Lebanon. Geophys. J. Int. 168: 1021-1028.

Gonano, L.P., \& Sharp, J.C., 1983. Critical evaluation of rock behavior for in situ stress determination using over-coring methods, in Proc. $5^{\text {th }}$ Cong. Int. Soc. Rock Mech. (ISRM), Melbourne, Balkema, Rotterdam, pp. A241-250.

Gray, W.M., \& Barron, K., 1971. Stress determination from strain relief measurements on the ends of boreholes: planning, data evaluation and error assessment, in Proc. Int. Symp. on the Determination of Stresses in Rock Masses, Lab. Nac. of Eng. Civil., Lisbon, pp. 183-199.

Hast, N., 1958. The measurement of rock pressure in mines. Sveriges Geo. Undersokning, Ser. C., No. 560.

Hakala, M., 2006. Quality control for over-coring stress measurement data. Tech. rep., Posiva, Posiva Oy FI-27160 Olkiluoto, ISBM 951-652-126-6. Finland, pp. 106.

Hakala, M., Hudson, J.A. \& Christiansson R., 2003. Quality control of over-coring stress measurement data. Int. J. Rock Mech. Min. \& Sci. Special issues 7-8. 40: 1141-1159.

Herget, G., 1973. First experiences with the CSIR tri-axial strain cell for stress determinations. Int. J. Rock Mech. Min. Sci., 10: 509-522.

Herget, G., 1993. Over-coring techniques, in Lecture Notes of the Short Course on Modern In situ Stress Measurement Methods at the $34^{\text {th }}$ US Symp. Rock Mech., Madison, Wisconsin.

Heusermann, S. \& Pahl, A., 1983. Stress measurements in underground openings by the over-coring method and by the flat jack method with compensation, in Proc. Int. Symp. on Field Measurements in Geo-mechanics, Zurich, Balkema, Rotterdam, pp. 1033-1045.

Khedher, K., 1992. Stresses measurement using the over-coring method: Influence of dip direction and dip of borehole on the quality of results. Master Degree Thesis in INPL-LAEGO High National School of Geology at Nancy. pp. 47.

Lahaie, F., 2010. Over-coring campaign from third to $18^{\text {th }}$ of November 2008 in the experimental station of Tournemire. Technical report of INERIS. INERIS DRS-10-97197-04334A.

Lahaie, F., 2006. In-situ determination of tensor stresses around tunnel and ground works of the over-coring experimental station of Tournemine. Progress and preliminary results of measurement campaign during December and January 2006. Technical report of INERIS. INERIS DRS-06-71871/RN01. pp. $49 \& 100$ appendices.

Lahaie, F., Gunzburger, Y., Ben Ouanas, A., Barnichon, J.D., Bigarre, P., \& Piguet, J.P., 2010. Impact of epoxy glue curing time on the quality of over-coring stress measurements in low temperature environments. Proceeding of the $5^{\text {th }}$ International Symposium on In-situ Rock Stress and Earthquakes, Beijing, China, 25-27 August 2010 Xie (ed.), Taylor and Francis Group, London, ISBN 978-0-415-60165-8, pp. 161-166.

Lempriere, B.M., 1968. Poisson's ratios in orthotropic materials. J. Am. Inst. Aeronaut. Astronaut. 6: 2226-2227.

Liu, X., Li, M. \& Huang W., 2002. Finite deformation elasto-plastic theory based on logarithmic strain and consistent algorithm. Acta Mechanica Solida Sinica. Vol. 23, pp. 24-33.

Nechenech, A., 1998. Numerical modeling of overcoring problem: Influence of behavior law of rock. PhD Thesis of INPL-LAEGO High National School of Geology at Nancy.

Ouanas, A.B., 2010. Measurement interpretation of deformation in anisotropic terrain: back to experience of CSIRO cell used in Tournemire clay (Aveyron), PhD Thesis. University of Nancy, INPL-LAEGO.

Ouanas, A.B., Gunzburger, Y., Lahaie, F., Piguet, J.P. \& Barnichon J.D., 2010. Mechanical testing of hollow cores to determine elastic parameters of anisotropic rocks using the CSIRO HI cell. Lausanne, Swiss, Proceeding of the European Rock Mechanics Symposium (Eurock 2010), Zhao, Labiouse, Dult \& Mathier (eds) Taylor \& Francis Group, London, ISBN 9780-415-58654-2, pp. 103-106.

Park, K.H. \& Kim Y.J., 2006. Analytical solution for a circular opening in an elastic-brittle-plastic rock, International Journal of Rock Mechanics and Mining Sciences, vol. 43, no. 4 pp. 616-622.

Pickering, D.J., 1970. Anisotropic elastic parameters for soils. Geotechnique 20: 271-276. 
Sharan, S.K., 2005. Exact and approximate solutions for displacements around circular openings in elastic-brittle-plastic HoekBrown rock, International Journal of Rock Mechanics and Mining Sciences, vol. 42, no. 4 pp. 542-549.

Slimane, K.B., Cournut, A., Smet, J.F.D. \& Trentesaux, C., 1996. In situ study and modeling of the mechanical behavior of a large diameter vertical blind hole in marl, Int. Conf. on Deep Geological Disposal of Radioactive Waste, Winnipeg, pp. 671-680.

Terzaghi, K. \& Richart F.E., 1952. Stresses in rocks about cavities. Geotechnique. 3: 57-90.

Walton, R.J. \& Worotnicki, G., 1986. A comparison of three borehole instruments for monitoring the change of rock stress with time. In Proc. International Symposium on Rock Stress Measurements, Stockholm.

Worotnicki, G., 1993. Tri-axial stress measurement cell, Comprehensive rock engineering, rock testing and site characterization. 3: 329-394.

Worotnicki, G. \& Walton J., 1976. CSIRO tri-axial stress measurement cell, Proc. ISRM Symposium on investigation of stress in rock, Supplement, 1-8, Institution of Engineers Australia, Sydney.

Zhang, Q., Li, C., Min, M., Jiang, B. \& Yu L., 2017. Elastoplastic analysis of circular openings in elasto-brittle-plastic rock mass based on logarithmic strain. Mathematical Problems in Engineering. Article ID 7503912 pp. 1-9.

Zhang, Q., Jiang, B.S., Wang, S.L., Ge, X.R. \& Zang H.Q., 2012. Elasto-plastic analysis of a circular opening in strain-softening rock mass. International Journal of Rock Mechanics and Mining Sciences, vol. 50, pp. 38-46. 